\title{
EXAMINATION OF HABAN VESSELS WITH URANIUM-BEARING BLUE GLAZE
}

\author{
Anna Ridovics ${ }^{1}$ - Zoltán MAY $^{2}$ - Bernadett BAJNÓCZI ${ }^{3}$ - Mária TóTH ${ }^{4}$ \\ ${ }^{1}$ Hungarian National Museum, Múzeum krt. 14-16, H-1088 Budapest, Hungary \\ E-mail: anna.ridovics@gmail.com \\ ${ }^{2}$ Institute of Materials and Environmental Chemistry, Research Centre for Natural Sciences, Hungarian \\ Academy of Sciences, Magyar tudósok körútja 2, H-1117 Budapest, Hungary \\ E-mail: may.zoltan@ttk.mta.hu \\ ${ }^{3,4}$ Institute for Geological and Geochemical Research, Research Centre for Astronomy and Earth Sciences, \\ Hungarian Academy of Sciences, Budaörsi út 45, H-1112 Budapest, Hungary \\ E-mails: ${ }^{3}$ bajnoczi.bernadett@csfk.mta.hu; ${ }^{4}$ toth.maria@csfk.mta.hu
}

\begin{abstract}
From the mid-15th century "berettino", or "turchino", lighter and darker, deep blue, cobalt-bearing glazes were used on Italian maiolica objects. At first such vessels were made mainly in Faenza, later they spread to Northern Italy and from the $17^{\text {th }}$ century they became popular throughout Europe. According to written sources and archaeological finds, potters working in the Anabaptist-Hutterite settlements used blue glaze right from the start. From the second half of the $17^{\text {th }}$ century there was an increase in the quantity of light and dark blue vessels that were made in many places. In the course of archaeometric research using a handheld X-ray fluorescence spectrometer (XRF), more than 500 Hutterite and Haban objects were analysed; of these circa 140 had a blue glaze. The measurements made on blue glazes and decorations found uranium in addition to cobalt in 107 objects. Some of the $17^{\text {th }}$ century vessels and stove tiles were made in Alvinc (Vințu de Jos, Romania), Sárospatak, and probably in Szobotist (Sobotište, Slovakia). The vessels with a blue or a white glaze, generally painted roughly with a brush, form a characteristic group provisionally attributed to a "mining town workshop". Their production began at the end of the $17^{\text {th }}$ century and was passed on by tradition until the $1780 \mathrm{~s}$. The workshop probably operated in the vicinity of a mining town in the former Zólyom county, along the upper reaches of the Garam river, in the vicinity of Besztercebánya (Banská Bystrica, Slovakia).
\end{abstract}

Keywords: Hutterite, Haban ceramics, blue glaze, cobalt, uranium, jugs with miners' symbols, Sárospatak, Besztercebánya, Alvinc, Szobotist

\section{INTRODUCTION - THE EARLY, ITALIAN USE OF COBALT BLUE GLAZE}

Light and dark, deep blue glazes ("berettino" or "turchino") (RAVANELla GuidotTi 1998: 306-330; RUfFini et al. 2005: 249) were used on Italian maiolica objects from the mid- $15^{\text {th }}$ century. The use of cobalt as a colouring material in the decoration of ceramics had long been popular in Chinese and Islamic art (ZucchiatTi et al. 2006:132). The raw material used for the so-called "Mohammedan blue" was mined in the Middle East and 
Asia, mainly in Persian and Arab territories, as well as in India. One of the first examples of the use of cobalt in Italy was on the glazed roof tiles of Giotto's Campanile in Florence around the 1300s; later it gradually became better known (Tiтe 2009: 2066) Around 1400 we find it as a pigment in the motives decorating the "Italo-Moresque" and "zaffre" style vessels in North Tuscany (BLAKE 1981; FABRI et al. 2000). From the second half of the $15^{\text {th }}$ century the Robbia family of Florence played an important role in the development of brilliant, high quality tin maiolica glazes, especially for plastic works (ZuCCHIATTI et al. 2006:131-152). The first blue-glazed vessels were produced mainly in Faenza; later use of the blue glaze spread to the Northern Italian cities of Venice, Savona, Albisola and Genoa (RufFini et al. 2005: 251). From the $17^{\text {th }}$ century it became popular throughout Europe wares of this type were made in Southern Italy (Laterza), France (Nevers), Switzerland (Winterthur), and in England, in the London pottery workshops. We know from "I tre libri dell'arte del vasajo" (The three books of the potter's art), a manuscript written by Picolpasso around the 1550s, that the blue colour was made from (roasted) cobalt ore, zaffre obtained through Venice(Picolpasso 2007: 66). The development of glass-making had a deep influence on the trend in Renaissance ceramics (GRATUZE 1996). The raw cobalt ore - which is accompanied by nickel, arsenic and a little iron - was heated and roasted to remove the impurities. The resulting cobalt oxide was the zaffera, zaffre - in German Saf(f)er(blau), Zafferblau, Safflor (JeRvis Jones 1841/2013: 103-104; KAPF 1792). At first, cobalt oxide resulted as a by-product from the processing of silver ore, then around 1520 a technological change occurred in the wake of an innovation introduced in the SaxonBohemian Ore Mountains (Erzgebirge). From then on the ore was mined separately and roasted in a new type of furnace (ZuCCHIATTI et al. 2006: 149-150). Related to this technological change, that is after around 1520, a detectable amount of arsenic appears in the zaffre (ZuCCHIATTI et al. 2006). From the early $16^{\text {th }}$ century smalte - in German: Schmalte, Schmalz, Schmelz - , that is cobalt-oxide-silicate, fritted ground blue glass coloured with zaffre, served for the creation of quality blue pigment, that was used by potters to produce glazes, as well as by painters. Cobalt pigment came to be produced on an industrial scale in Saxony and the Czech lands using raw material from the Ore Mountains (Zucchiatti et al. 2006: 132). Around 1570 blue cobalt glass was already being produced in the Czech glass workshops (KAPF 1792).

\section{BLUE GLAZE ON HUTTERITE CERAMICS IN THE $16^{\text {th }}$ TO $17^{\text {th }}$ CENTURIES}

The spread of tin-glazed ceramics in Eastern-Central Europe can be linked largely to the activity of Anabaptist-Hutterite masters - generally referred to in the literature as Habans ${ }^{1}$, but in Hungary they have often been called Neo-Christians. Their faience production can be documented in the territory of Moravia from the late 1580s and 1590s. The first Anabaptist communities representing the third branch of

\footnotetext{
${ }^{1}$ We use this expression for the masters after the disintegration of the Hutterite settlements based on collective payment of taxes and common ownership of assets $(1685 / 86)$.
} 
the Reformation were formed in Swiss territory in the 1520s and soon appeared also in the neighbouring countries. They functioned as a free Protestant church independent of the secular authorities. Their members were baptised as adults following their own personal decision (SzEBENI 1998: 11). Right from the outset they were persecuted because of their religious tenets. Their groups arrived in Moravia in successive waves from Switzerland, Southern Germany, Tyrol, Austria and Italy. The potters working in the communal Anabaptist-Hutterite settlements here were familiar with the ceramic traditions and latest achievements of Italian and South German Renaissance ceramics. According to data in written sources, such as the 1588 Neumühl potters' rules (Hafner Ordnung), they also knew about blue glaze (HoRvÁTH - KRISZTINKOVicH 2005: 202). A blue stove was ordered from the Anabaptists in 1589 for the Bishop of Olmütz, Stanislav Pavlovský (PAJER 2006: 182; VIDA 2008: 165). The rules of 1594 mention the production of blue and white tankards (HoRvÁTH - KRISZTINKOVICH 2005: 203). This is also confirmed by the finds excavated by Jiří Pajer in the Moravian settlements (PAJER 2001: 111, 115, 171). However, with the increasingly strict principles of the community's way of life, the rules issued on $11^{\text {th }}$ December 1612 in Szobotist ordered that the members surrender all bone-white, blue, and other similar vessels with pewter fittings (Katona 2001: 150-151). For their own use the Anabaptist brethrens were to make only black, yellow, green or plain unglazed earthenware vessels. Blueglazed products were popular in aristocratic courts. In Western Hungary the 1635 inventory of the Batthyány family's pharmacy in Rohonc (Rechnitz, Austria) lists a blue horticultural vessel, vinegar jug, pots with handles, cups for jam (lictarium), and bowls and plates (KATONA 1969: 601). Blue-tiled stoves used to heat the living spaces and at the same time as decoration are frequently mentioned in Batthyány family inventories, generally in the lord's room. There is a record of two in Dobra (Neuhaus am Klausenbach, Austria) (1645), in Rohonc (1645) one blue stove, that is a tiled stove, stood in the lord's room, there was a white stove in the lady's room, and green stoves elsewhere (Katona 1969: 603). But not in all cases. In Németújvár (Güssing, Austria) (1646) the stove in the pharmacy was green, there was a white-glazed stove in the lady's first room, a blue one in her bedroom and also in the lord's room (KATONA 1969: 604). The earliest known intact blue-glazed, light-coloured vessel is a round-bellied jug (Prague, Museum of Applied Arts, Inv. 11.107) bearing the date 1620; it was probably made in Moravia (Kybalova - Novotna 1981: 65; PAjer 2011: 79). Decorative ceramics were also made in the principality of Transylvania by the Anabaptist Moravian brethrens settled in Alvinc by Gábor Bethlen in 1622. His wife treasured these pieces. But so far we have not been able to identify any of them with full certainty. In the Transylvanian material the earliest known piece is a blue jug from 1651 (BunTA 1973: 39). It is well known that Anna Bornemisza, consort of the prince, recorded in her estate diaries that in the years 1667-1690 the Anabaptists of Alvinc made not only white-glazed dishes, cups, jugs with mouthpiece, water jug, large jugs, but also the same types of vessels in blue-glazed variant, bringing them to the prince's court as a New Year's gift (BunTA 1973: 31, after SzÁDECZKY 1911). According to the evidence of the surviving objects, a growing quantity of light and dark blue vessels was produced 
from the second half of the $17^{\text {th }}$ century. They were made in many places, but further thorough research is required to identify more precisely the places where individual products were made. ${ }^{2}$

\section{VESSELS WITH URANIUM-BEARING BLUE GLAZE AND DECORATION}

Research supported by the Hungarian Scientific Research Fund (OTKA) began in 2010 with the aim of bringing together, including in a database, and systematising the Hutterite, Haban ceramics stored in public and private collections in Hungary (RIDOVICS 2013). A separate question was to identify the technology used for blue-glazed ceramics and locate the place where they were made; stylistic analyses and also archaeometric methods are being used to answer this question. In the course of the archaeometric research we used a non-destructive handheld X-ray fluorescence spectrometer (XRF) to analyse the chemical composition of the body, glaze and decorations (BAJNóczi et al. 2015). Up to February 2015 we examined more than 500 Hutterite as well as Haban, Late Haban and Post-Haban objects. ${ }^{3}$ Of these, around 450 pieces were glazed; a third, approx. 140 pieces (dark and light), were blue-glazed: 87 pieces were museum objects (vessels, 2 stoves, 7 separate tiles), the remainder were archaeological fragments of varying size. In 70 cases the measurement showed the presence of uranium accompanying the cobalt in the blue glaze - in 46 vessels, 4 stove tiles and the stove from Liptónádasd (Trstené, Slovakia) and 19 archaeological finds. In addition to the vessels with a blue glaze, uranium was found in 37 cases in the blue decorations applied on a white glaze - for the most part vessels, as well as the stove from Gyulafehérvár (Alba Julia, Romania), tiles unearthed in two excavations, three stove tiles in museums, and 4 archaeological fragments from the Historical Museum in Kolozsvár (Cluj-Napoca, Romania). In total, the measurements showed uranium as well as cobalt in the blue glazes and decorations of 107 objects (20 ppm -0.24 weight $\%$ uranium) (Fig. 1$)^{4}$. This is an entirely new result that had not been

${ }^{2}$ Horváth - Krisztinkovich 2005: 202; Béla Krisztinkovich (Krisztinkovich 1962: 39) identifies the place where blue-glazed vessels were made in the $17^{\text {th }}$ century as Alvinc; Mária Krisztinkovich considers that they were made in Alvinc rather than in Northern Hungary. In general they cite Magda Bunta. Cobalt was rare and costly in Moravia and Northern Hungary, while in Alvinc it was plentiful and tin was rare. BunTA 1973: 38-39.

${ }^{3}$ Measurements have been made on the objects of the following collections (see together with the identifying abbreviations before the inventary number): the Museum of Applied Arts (IMM, Budapest), the Hungarian National Museum (MNM), the Museum of Ethnography (NM, Budapest), the Budapest History Museum (BTM), the Rákóczi Museum of the Hungarian National Museum (Sárospatak), the Scientific Collections of the Reformed College of Sárospatak (SRK), the Transylvanian National Historical Museum (KTM) and the Transylvanian Museum of Ethnography (ENM) (Cluj-Napoca, Romania), the Collection of the Roman Catholic Episcopacy of Alba Julia (Romania) and the Batthyaneum (Alba Julia, Romania), the ASTRA Museum (Sibiu, Romania), the Museum of Folk Life and Folk Art (ÖMV, Vienna, Austria). Findings of the excavations in Moravia were studied with the help of the archaeologist Jiří Pajer in the Czech Republic.

${ }^{4}$ Uranium was also detected in three vessels with sgrafitto (Museum of Ethnography 51.30.771, ViennaÖMV 23.901; 35.148), two tiles from Farkashida (IM 6558.14; 6558.443) and a glass object (IM 2815), but we will not discuss these here. 


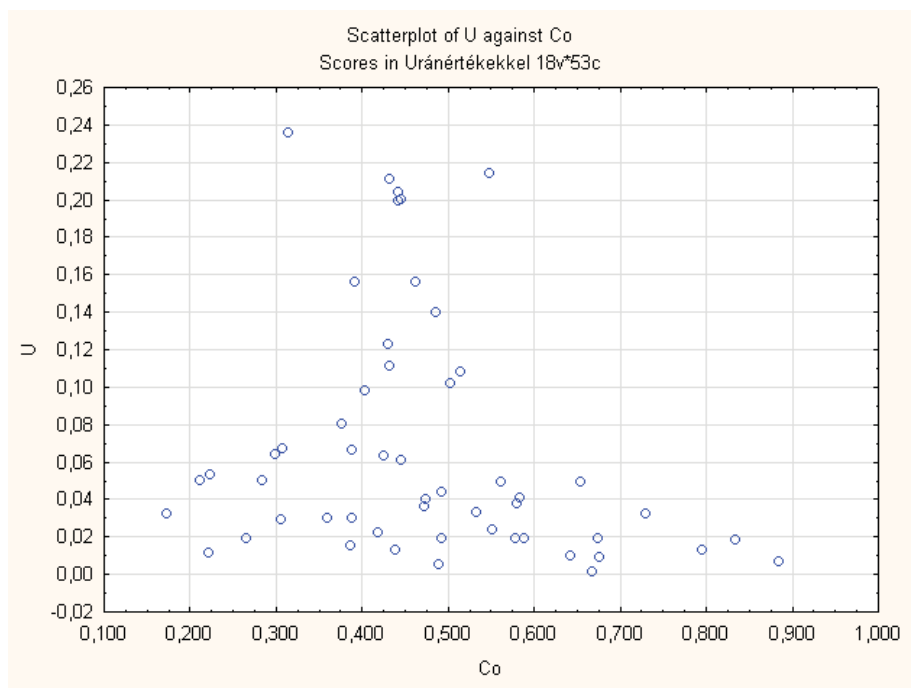

Fig. 1. Uranium concentration (weight $\%$ ) as a function of cobalt concentration (weight $\%$ ) in the blue glazes measured by handheld XRF

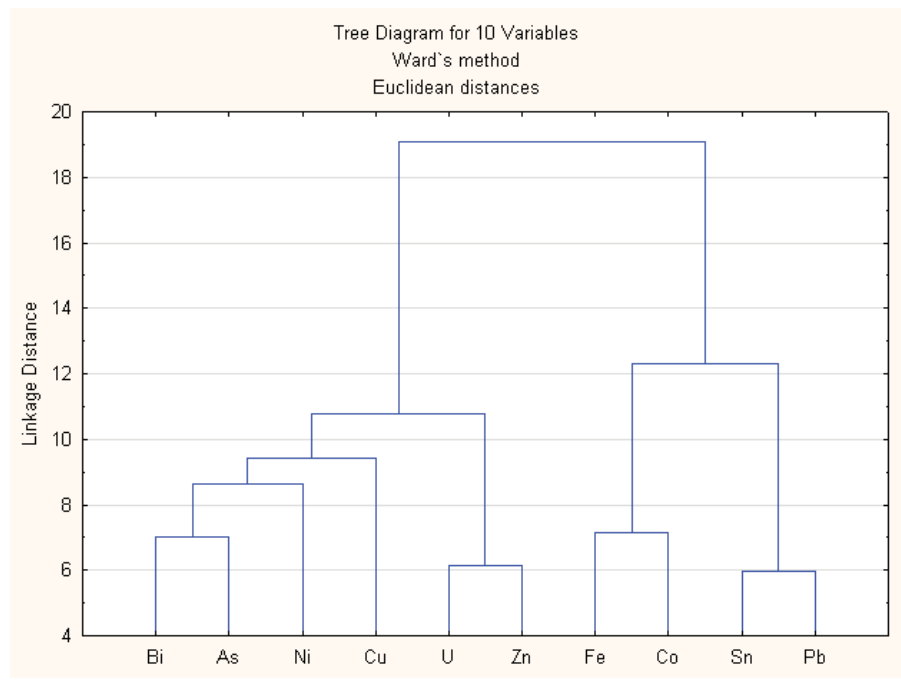

Fig. 2. Dendogram (Tree diagram) for the elements measured by handheld XRF in the blue glazes

found by the previous research. Among the components of the blue glaze a significant $(p<$ 0.05 ) correlation can be observed between the uranium and the zinc (Fig. 2); this can provide information on the place of origin of the cobalt pigment (the cobalt ore deposit) and so indirectly can help to determine where the objects were made. The provenance of Haban objects preserved in museums is often uncertain, many pieces entered public collections 
from private collections; they can be classified on the basis of stylistic and chronological considerations. We first take these considerations into account to analyse the collection pieces, and then the archaeological finds. We take the date appearing on vessels to be the year in which they were made; on this basis we separated the objects made in the $17^{\text {th }}$ century from those made in the $18^{\text {th }}$ century. The pieces not marked with a year were dated on the basis of stylistic considerations.

\section{$17^{\text {TH }}$ CENTURY FAIENCE WITH URANIUM-BEARING BLUE GLAZE AND DECORATION}

At present we classify 13 ceramic vessels with blue glaze in the $17^{\text {th }}$ century group (3 dishes, 3 tankards, 2 jugs with strainer, 2 angular bottles, 1 pear-shaped jug, 1 round-bellied jug, 1 jug with flanged handle). We also included here the damaged, burnt tankard (MNM 1961.3330) with a date that is difficult to decipher, 1651(?) (Plate 4). These have a tin-bearing blue lead glaze (BAJNócZI et al. 2015), a floral decoration of white lines generally coloured with yellow and green, mostly with a brownish-black contour emphasising the outline. One dish (1690, MNM 1885.11.) (Plate 4) and the small, pear-shaped jug (1691, IMM 2885)5 (Plate 1) are decorated with white only. Ten vessels are marked with a year. The earliest (not counting the damaged tankard) is from 1653; it is an elegantly painted square bottle (IMM $2845 \mathrm{ab})$ decorated on four sides with a rich floral ornamentation and an Italian vase motive ${ }^{6}$ (Plate 1). An unusually deep dish (ENM A 1566) with a broad rim has the year 1664 in the well with a flowering plant (RoșCA - KLusch 2010: 520; RAdVÁNYI - RÉTi 137, Fig. 182) (Plate 1). On the rim there are three wavy tendrils with three flowers (rosette with radiating petals) and also unusually the tendrils are separated with braided vertical lines. The master who made the jug (KTM F79) dated 1672 used two kinds of decoration: there is a white wavy tendril in the central part of the decoration in three bands, above it between two upright white flowering plants there are three flowers drawn in contour with green stamens, the petals and leaves filled in with white (Plate 1). The date appears on the neck (BunTA 1973: 91, 17b; RADVÁNYI - RÉTi 147, Fig. 200). The other vessels were made in the 1690s: two dishes (1690 (MNM 1885.11), 1695 (MNM 1973.10. G:G:/A: Ku: monogram) (Plate 4, Plate 6), a small jug with pear-shaped body but wide neck and mouth (1691, IMM 2885) (Plate 1) and a narrow-mouthed, round-bellied jug with flanged handle (1695, IMM 2873) 7 (Plate 1), 1 tankard (1694, IMM 74.55.1) (Plate 1), 1 angular bottle (1696, ENM A 2314)(RoşcA - KLusch 2010: 518) (Plate 1). Two jugs with strainers (IMM 14284, IMM 14276) 9 (Plate 2), a tankard (IMM

${ }^{5} \mathrm{http}: / / g y u j t e m e n y . I M M . h u / g y u j t e m e n y / b o k a l y-o n f e d e l l e l / 12103$, with further literature, Transylvania.

${ }^{6} \mathrm{http} / /$ gyujtemeny.IMM.hu/gyujtemeny/fuszertarto-palack-csavaros-onfedellel/1103, Transylvania.

${ }^{7}$ http://gyujtemeny.IMM.hu/gyujtemeny/korso/2657, with further literature, Transylvania.

${ }^{8} \mathrm{http} / /$ gyujtemeny.imm.hu/gyujtemeny/kupa/11873

${ }^{9}$ IMM 14284; Bunta 1973: 75. Transylvanian work; Katona 1974: 64, 214; Balla 1988: 154, item 525. $2^{\text {nd }}$ half of $17^{\text {th }}$ century; HoRvÁth - KRISZTINKOVICH 2005: 232-233; http:/gyujtemeny.IMM.hu/gyujtemeny/ korso/2298, Upper Hungary around 1690; IMM 14.276.; BUnTA 1973: 75. Transylvanian work; KATONA 1974: 67, 215; HoRváth - KrisZTinKovich 2005: 232-233. 
2871) with a ceramic $\operatorname{lid}^{10}$ (Plate 1) and a fluted bowl on stand (NM 107971) ${ }^{11}$ (the latter $17^{\text {th }}$ or $18^{\text {th }}$ century?) have no date, but on the basis of similar pieces we date them to the second half or end of the $17^{\text {th }}$ century. The stove from Liptónádasd (Plate 5) and the four stove tiles in the Museum of Applied Arts ${ }^{12}$ are also traditionally placed in this period in descriptions. The representative stove (MNM 1927.63) from the castle of the Baán family in Liptónádasd came into the possession of the Hungarian National Museum in 1927 (Ridovics 2002: 473). The tiles around the body of the stove and decorating the corners have a plastic plant ornamentation on a blue ground (winding tendrils with tiny flowers in a line or facing each other in mirror symmetry, with large plant motifs with seeds and serrated hem) and the edges are emphasised with a white tin glaze. Analogies exist in two other blue-glazed stoves, one (IMM 6542) from the Turcsányi house at Besztercebánya in the Museum of Applied Arts ${ }^{13}$ and the stove from the Andrássy castle in Krasznahorka (Krásna Hôrka, Slovakia). Single and mirror symmetrical tendril motives dominate among the tiles of the Besztercebánya stove, but occasionally there is a mirror symmetric motif similar to those from Krasznahorka, composed in an arc. We were able to measure the first two, but the results differed. ${ }^{14}$ We identified uranium only in the stove from Liptónádasd. However, uranium was present in the four separate blue stove tiles in the Museum of Applied Arts: in the corner tile (IMM 52.3762) with a painted plant ornamentation on its raised edges (Plate 5), the thin, floral tile fragment (IMM 53.5086) and the leaf shape (IMM 52.3770) forming the top, and the profiled elements (IMM 10.220.2.) of the pediment that are only painted.

The decoration of floral tendrils and upright flowering plants of Hutterite, Haban ceramics can also be observed on the $17^{\text {th }}$ century vessels with a white glaze and painted with characteristic colours (copper green, antimony yellow, manganese brownish black), and blue decorations containing cobalt with uranium. They include four dishes (1669, MNM 61.2151 C; 1692, MNM 54.436; 1695, IMM 21814, IK monogram, 1965, IMM 1956. $390)^{15}$ (Plate 3), two jugs (a small, round-bellied jug (MNM 54.408) with the date 1655 and an elongated, oval-shaped, fluted one with the date 1679 (MNM 1961.404) (Plate 3), a big pear-shaped jug (1691, SRK F. 1904.1), ${ }^{16}$ as well as two jugs with strainers (1671, IMM $2866^{17} ; 1661$ ? ENM A 2317) ${ }^{18}$ (Plate 2). The fan-shaped stove crest tile decorated with an

10 http:/gyujtemeny.IMM.hu/gyujtemeny/kupa-onfedellel/1807, with further literature, Transylvania, around 1660-1670; BunTA 1973: 83, 1650-1655.

${ }^{11} \mathrm{http}: / /$ public.neprajz.hu/neprajz.01.03.php?bm=1\&kv=8660280\&nks $=1$, North-West Hungary, $17^{\text {th }}-18^{\text {th }}$ century, description by Gabriella Vida.

${ }^{12}$ IMM 52.3762.1. KATONA 2001: without page numbering; IMM 53.5086; IMM 52.3770; IMM 10.220.2

13 http:/gyujtemeny.IMM.hu/gyujtemeny/kalyha-a-besztercebanyai-turcsanyi-bethlen--hazbol/1554 mid-17th century; RADVÁNYI 2013: 57-70. The most recent overview of the subject.

${ }^{14}$ We did not find uranium in the blue glaze applied on the stove from Besztercebánya. But Diána Radványi raised the possibility that among the separate tiles with uranium-bearing blue glaze in the Museum of Applied Arts, some pieces may have belonged to the Besztrecebánya stove that could have been put together from several different stoves. So it will be necessary to repeat the measurement.

${ }^{15} \mathrm{http} / /$ gyujtemeny.IMM.hu/gyujtemeny/tal/11876, with further literature.

${ }^{16}$ Pocsainé EperJesi 2010: 215. It was a communion vessel of the Calvinist church in Átány.

${ }^{17}$ http://gyujtemeny.IMM.hu/gyujtemeny/korso/1809, with further literature, Transylvania, 1671.

${ }^{18}$ The dating on the jug is very unusual, the figure 16 is written on both sides of the handle. Read together this gives the year 1616. It is certain that vessels of this shape were not yet made at that time. Perhaps the potter who painted the date was careless. Presumably he meant to write the date 1661 but switched the order of the 
Italian vase motive and flowers but without a date (KTM F 3147) ${ }^{19}$ from the Transylvanian Historical Museum is an exact pair of the piece found during the excavations at the Rákóczi castle in Sárospatak (VIDA 2008: 73; Gyurica 1992: 300). There are three stove tiles in the Museum of Applied Arts. Two without frame are decorated with an endless pattern. ${ }^{20}$ The edge of the geometric motive determining the structure of the pattern is emphasised with blue paint. The plant motives that fill the spaces are either left white or are coloured, generally painted blue. The third tile with a white glaze represents the mirror symmetric flowering plant motive set in a framed panel (Plate 5). Its dominant element is a multi-layered lance-shaped flower of oriental appearance with hems seen from the side (leaf flower, pomegranate?) arranged in facing pairs, emphasised with blue (IMM 3626). The stove from Gyulafehérvár reconstructed in the early 2000s will be discussed in more detail in connection with the archaeological finds.

Six of the seven (blue and white) $17^{\text {th }}$ century dishes show the manner of composition popular for the decoration of Haban dishes. In the well of the dish there is a bunch of flowers, an upright flowering plant, and around on the broad rim there are three floral tendrils and bunches with similar motive and colouring. One blue dish (MNM 1885.11) (Plate 4) has only the date 1690 in a radiating frame, and in the centre a bunch of flowers in white without a dark contour, with a double stripe around it. There is no dark contour either on the white, green and yellow pomegranate tendrils on the blue dish with the date 1695 (MNM 1973.10). The reverse side of four dishes is entirely covered with glaze in a manner characteristic of the majority of $17^{\text {th }}$ century Hutterite, Haban dishes - with an indented, turned centre or a low vertical foot edge. On three dishes, one blue-glazed and two whiteglazed, all the three dated 1695, we find a solution that later came to characterise a certain type of $18^{\text {th }}$ century dishes (MNM 1973.10; IMM 21.814) (Plate 6, Plate 3). The bottom shaped at an angle is entirely unglazed, the middle is slightly turned forming an foot rim a good centimetre wide. The marriage dish of Joannes Berzewiczi and Marisli Ewa dated 1695 can also be linked to this group (IMM 56.390) ${ }^{21}$.

\section{THE ARCHAEOLOGICAL FINDS}

Measurement of the archaeological finds showed that of 58 pieces, 23 (19 with blue plus 4 with white glaze) contained uranium. The distribution of the sites where they were found was: 7 fragments (out of 17 blue pieces) from the area of the former Haban settlement in Sárospatak, 2 fragments (out of 15 blue pieces) from the Budapest History Museum's excavation in Buda Castle, 1 (out of 2 blue pieces) from Szobotist and 11 fragments

figures, or accidentally wrote the beginning of the date twice and was no longer able to correct it; BunTA 1973. 49 published the object with the date 1676; Roșca - KLusch 2010: 524 published the object with the date 1616 without any commentary.

${ }^{19}$ Purchased from Adolf Resch in 1903; BunTa 1973: 95-96. No. 21, 1tsz. I 3354. At one time it was in the collection of the former Transylvanian Museum.

${ }^{20}$ IMM 52.3610.1; http://gyujtemeny.IMM.hu/gyujtemeny/kalyhacsempe/12098 (thought to be) $17^{\text {th }}$ century; IMM 3575 http:/gyujtemeny.IMM.hu/gyujtemeny/kalyhacsempe/12107 lead-glazed?

${ }^{21}$ IMM 56.390.1 http//gyujtemeny.imm.hu/gyujtemeny/tal-berzeviczy-janos-es-mariass-uvanamara/11900 
from the Alvinc material in the Transylvanian Historical Museum (out of 16 pieces), 2 fragments (out of 8 finds) from the excavation in Gyulafehérvár around the former episcopal palace, and the stove tiles found during the alterations. During the excavations led by István Ringer in 2010 and 2012 in the Haban settlement in Sárospatak, on the site in today’s Kövi Sándor utca 87 pieces of varying size, most of them very small with various shades of blue glaze, were found; of these 27 could be identified as parts of vessels (RINGER 2014: 144; Ringer 2015). Ringer assumed that they must have been kiln waste. We measured 17 of these fragments and found uranium in the blue glaze of 7 pieces. Three tiny pieces were from the same object. The workshop find representing the remains of the glaze dribbled onto the kiln supporting that they must have belonged to the as yet unexcavated potter's kiln in Sárospatak is especially important (RINGER 2014: 135, Table 112). It would provide firm proof that blue-glazed vessels containing cobalt with uranium were definitely made here. György Rákóczi I settled Anabaptists here in Sárospatak in 1645, in the Héce area beside the River Bodrog, where they lived until the mid-1680s. After that they moved away to avoid the forced conversion to Catholicism, or integrated into the local population. The excavation finds from Szobotist came into the possession of the Museum of Ethnography in 1962 as a gift from Heřman Landsfeld; the notes on the pieces were made by Mária Kresz on the basis of information given by Landsfeld. ${ }^{22}$ Of the 45 fragments, one is from Kosolna (Košolná, Slovakia), the remainder are from Szobotist and Holics (Holíč, Slovakia). There is no attached data on the date or circumstances of the excavation. Of the two badly fired blue-glazed fragments, presumably unearthed as workshop finds, piece No. 5 (NM 2013.54.5) from Szobotist ${ }^{23}$ contains uranium in the blue glaze. The blue glaze shrank and the vessel became smoky. According to the note attached to the fragment, it was probably made around 1650. From the Buda Castle material in the Budapest History Museum we were able to examine tiny glazed fragments unearthed during the excavation led by Anikó Tóth. The excavation on the site at Budapest $1^{\text {st }}$ district, Csónak utca 1-3 was in the stratum predating the construction of the Gold Bastion and the finds can be dated to before 1685. It is possible to draw conclusions regarding the place and time of use from these fragments. Uranium was found together with the cobalt in 2 of the 15 blue-glazed fragments. The bottom of the fragment (BTM TA 14) of a roundbellied jug has a lighter blue glaze on the inside and a darker blue on the outside. The latter contains uranium. The fragment of the jug (BTM TA 25) is light blue on the outside and has a white glaze on the inside. Below the edge there is a decoration of double black lines. According to the inventory book, finds marked F 19. ... preserved in the Transylvanian Historical Museum in Kolozsvár (F 19.662 - fragment of a stove tile, on the white lead-glazed base the raised leaf parts have been emphasised with blue painting. F 19.664, F 19.669, F 19.670, F 19.677 fragments of vessels, F 19.642 fragment of the bottom of a small bowl, white glazed with a coloured decoration) came from the excavation in Alvinc in September 1970 (S III/b -0,50-0,70). We do not know of any written material giving a more precise localisation or describing the circumstances of the excavation. Magda Bunta

\footnotetext{
${ }^{22}$ Gabriella Vida found the fragments when the stores were rearranged in 2014. We thank her for drawing our attention to them. For more details on the fragments see her article in this volume, VIDA 2015.

${ }^{23} \mathrm{http} / /$ public.neprajz.hu/neprajz.01.03.php?bm=1\&kv=8660280\&nks=1, Ószombat, Nyitra County. mid-1 $17^{\text {th }}$ century, description by Gabriella Vida.
} 
refers a number of times to the excavation in Alvinc and in nearby Borberek and to the finds made there. ${ }^{24}$ In her book she published 10 stove tile fragments and 16 vessel fragments (BUNTA 1973: 32-33). Of these we were able to measure practically every glazed piece; cobalt with uranium was found in 4 pieces. Two pieces, one fragment with a white glaze and one with a blue are also from this excavation but are not included in Bunta's publication. The dating of the tiny fragments is rather uncertain. Considerations of style suggest that they could be placed in the second half of the $17^{\text {th }}$ century, but there were also a large number of $18^{\text {th }}$ century fragments in the assemblage. In 1772 there were still 6 potters, 3 jug-makers and 3 stove-makers active in Alvinc (BunTA 1973: 79). A reconstructed Haban tin-glazed stove stands in the dining room of the former princely, today episcopal palace in Gyulafehérvár (EMöDI 2009: 150, 402; EMöDi 2012: 171-175) (Plate 5). The tiles are decorated in relief and the raised, stylised plant motives placed mirror symmetrically are picked out in cobalt blue paint. The corner tiles are decorated with a rosette between two bundles of leaves. The profiled foot tiles and the onion-shaped tiles along the top crest and the pendant elements are decorated with a variety of plant and geometric motives. The stove tiles were discovered in 1996 in the rubble fill behind the barrel-vaulted main entrance passage, together with pieces of another green lead-glazed stove, and fragments that have been identified as wall tiles from the former tiled room. Emődi puts the activity of the Alvinc Anabaptists living in the vicinity to after 1666 for the tiled audience chamber and considers that the stove was probably set up between 1666 and 1687. Uranium could also be identified in two other fragments from the Gyulafehérvár archaeological assemblage: in two stove tiles painted with blue on a white ground. ${ }^{25}$ On the basis of these archaeological finds it can thus be said with certainty that vessels and stove tiles with cobalt pigment containing uranium were made in the $17^{\text {th }}$ century in two places: in Alvinc and Sárospatak, and probably also in Szobotist.

Among the museum objects, five can be found in collections in Transylvania, in the Transylvanian Historical Museum (the round-bellied jug (KTM F 79) dated 1672, the tile from the top of a stove (KTM F 3147) and in the collection of the Transylvanian Museum of Ethnography the dish dated 1664 (ENM A1566), the square bottle dated 1696 (ENM A 2314) and the jug with strainer from 1661? (ENM A 2317). The remainder are preserved in museums in Hungary: the National Museum and the Museum of Applied Arts that have purchased numerous objects from famous private collections in Transylvania. Although these may include objects from both the territory of the former royal Hungary and from Transylvania, the pieces, especially those with blue glazes that have entered from these collections, have in most cases been identified traditionally in the literature as having been made in Transylvania. The square blue bottle dated 1653 (IMM 2845ab), the undated blue tankard (IMM 2871) with a pottery lid and the white jug with strainer (IMM 2866) dated 1671 came to Budapest in 1888 from the collection of Count Jenő Lázár (1845-1900) of Medgyesfalva (Mureşeni, Romania); the museum purchased one of the blue jugs (IMM 14284) with strainer from Emil Sigerus of Nagyszeben (Sibiu, Romania) in 1917. The

\footnotetext{
${ }^{24}$ BunTA 1973: 16-17, 31-33, 37. She mentions them once as an excavation in 1969, and elsewhere as 1971.

${ }^{25}$ GyErGy A-K-79, GyErGy A-K-80; Marcu Istrate 2009: 147. Item 388 contains $17^{\text {th }}$ century pieces unearthed near the episcopal palace in the excavations made between 2000 and 2008.
} 
four different-sized jugs with strainers are similar in form (although one is fluted) and proportions. ${ }^{26}$ Their decorations have different motives but follow the same compositional order. They are probably the products of the same workshop, presumably from the $1660 \mathrm{~s}$ or 1670s. This type was unknown in the Hutterite ceramics of the Moravian settlements. The jug with strainer and a spout that widens like a funnel and is pinched together to form three lobes, with a flattened globe-like body and narrow cylindrical neck section followed the pattern of Ottoman-Turkish metal vessels; it is known in the territories that were occupied by the Turks and was transmitted through black ceramics of Balkan origin (HoRVÁTH - KRisZtinkOVich 2005: 232-233; Ridovics 2008, with further literature). The shape also has parallels in Transylvanian goldsmiths' work from the last third of the $17^{\text {th }}$ century (KIss 2008: I. 330-311). In the light of the finds from the excavations in Sárospatak, another possible localisation besides Transylvania arises for this type of jug with filter. The excavation of the Haban settlement led by Ringer unearthed a number of unglazed kiln wastes that had been fired only once (RINGER 2014: 160-161, Plates 167-168). The majority, but not all, were covered with a light engobe layer (RINGER 2015). They included fluted pieces, although in this case the fluting was diagonal. The description "jug for sour water" that according to the sources (DÉTSHY 1972: 132) the Anabaptists of Sárospatak were already making in 1647 , probably applies to this shape. Presumably, naturally carbonated mineral water was served in them.

\section{$18^{\mathrm{TH}}$ CENTURY VESSELS WITH URANIUM-BEARING BLUE GLAZE AND DECORATION}

In the $18^{\text {th }}$ century there is a substantial increase in the number of vessels with a uranium-bearing blue glaze - 31 all in all, forming one group as regards their style, the composition of their glaze and the production technique. Although it is present in very small quantities, the blue glaze always contains tin indicating its intentional use (BAJNóczi et al. 2015). A number of $18^{\text {th }}$ century vessels with a white glaze can be grouped into this stylistical circle -14 pieces all in all. Their shape, the manner of painting and the motives used for decoration link them to the same style and workshop. The characteristic shape and production technique can be first observed in three dishes made at the end of the $17^{\text {th }}$ century, in 1695 (MNM 1973.10; IMM 21.814; IMM 56.390.1). We know of two white dishes dated 1714 (IMM 2895; MNM 1963.130). Taking into account both groups (blue- and white-glazed), 35 pieces can be dated to between 1721 and 1738. But there is also one jug (MNM 61.2052) marked with the year 1748 and another bottle with 1763 (NM 51.33.271), ${ }^{27}$ and there are even two very late vessels among them (1770, MNM 54.344. dish; 1782, MNM 1954.382. jug). Four dishes are without a date. ${ }^{28}$ Among the 45 vessels the greatest number are dishes with

\footnotetext{
${ }^{26}$ IMM 14.276 - $22 \mathrm{~cm}$ plaster-reconstruction at the mouth, IMM $14.284-19 \mathrm{~cm}$, A $2317-19 \mathrm{~cm}$, IMM $2866-25 \mathrm{~cm}$.

${ }^{27} \mathrm{http}: / /$ public.neprajz.hu/neprajz.01.03.php?bm=1\&kv=8660280\&nks=1, Ge: Am: 1765, from the vicinity of Pozsony/Bratislava, description by István Csupor - Gabriella Vida

${ }^{28}$ MNM 1954.390, IMM 59.966.1, MNM 1954.397 Does not contain tin?, MNM 1961.452.
} 
wide rims (20 blue and 11 white), three larger and two smaller elongated, oval-shaped, socalled melon-bodied jugs with wide mouths; similar pieces are found among the $17^{\text {th }}$ century Haban products. ${ }^{29}$ The pear-shaped jugs (1722, IMM 2914), (1723, MNM 1961.462), (1724, NM 51.31.500), ${ }^{30}$ the round-bellied jugs with narrow necks and handles (1727, ÖMV 5.894), the rectangular bottle (1732, NM 51.33.271) and especially the ewers with pinched mouths (1726, MNM 1954.394), (1729, MNM 1954.393), (1748, MNM 61.2052) that first appear at the end of the $17^{\text {th }}$ century, are characteristic types by the $18^{\text {th }}$ century.

A few pieces with a white glaze decorated with the blue of cobalt pigment containing uranium (6 pieces) cannot be linked to the workshop mentioned above, as they differ in style. These were characterised by a stock of lightly sketched, often figural motives enriched with buildings on a white ground (floral linear patterns, dot-and-circle motive, cheerful figures, small horses and deer) that was increasingly popular from the early $18^{\text {th }}$ century. They are a distinctive Haban interpretation of "chinoiserie" (Plate 10). They include a round dish with a deep well and wide rim (MNM 1954.334), three small pearshaped joined jugs - known as the "three brethrens" or "Dreibruder" (MNM 69.105.1) Similar pieces to the fluted oval dish with blue decoration (MNM 54.412) are known from the turn of the $17^{\text {th }}$ to the $18^{\text {th }}$ centuries. The three albarellos form a separate unit with their curved frame motives painted in two shades of blue (camïeu blue), in which the name of the medicine could be placed later (MNM 1922.40; MNM 1950.305.1; MNM 1950.306.1) A more detailed examination of these pieces is a task for future research.

\section{THE "MINING TOWN WORKSHOP”}

In this study we attempt mainly to define more precisely the characteristic group of objects, all having the same style, with a blue or a white glaze and generally rather roughly painted with a brush. This group of objects is not unknown in the literature. A number of authors have dealt with it, most recently Pišutová, who has published new results. ${ }^{31}$ However, they have not yet been analysed more thoroughly or examined more precisely as a whole. At present more than 70 vessels can be classified to this workshop on the basis of considerations of style; 45 of these were measured. The thrown shape of the dish is characterised by a broad rim and a deep well. They are generally $28-32 \mathrm{~cm}$ in diameter. The shaping of the reverse side differs characteristically from that of the traditional Hutterite, Haban dishes that are strongly articulated with the bottom of the well rounded. The difference can be clearly seen from a comparison of the two different types of dish (MNM 1881.11; MNM 1954.366) (Plate 4). The reverse side of the well is barely perceptibly separate, the rim does not curve out so sharply but rather rises steeply. In cross-section the vessel opens out rather like a funnel. The bottom

${ }^{29}$ MNM 1954.445. MAR:SHA; 1725; IMM 29251726 http:/gyujtemeny.IMM.hu/gyujtemeny/kannabanyaszjelvennyel-georgius-bartha-1726-felirattal/2289; IMM 59.2248.1 http:/gyujtemeny.IMM.hu/gyujtemeny/kanna-banyaszjelvennyel/2306 1735; IMM 2900, MNM 1954.382.

${ }^{30} \mathrm{http}: / /$ public.neprajz.hu/neprajz.01.03.php?bm=1\&kv=8660280\&nks=1, Zólyom, collected by Elemér Kund, place of use Transylvania, Mária Kresz - Gabriella Vida.

${ }^{31}$ PIŠUtoví 2014. Unfortunately the article did not come to our attention until after the manuscript was completed, so we were not able to fully incorporate its results into our study. 
of the dish is always unglazed. A variety of motives are used for the decorations on the dishes and on the basis of the compositional system they can be divided into several main groups. Decorations in three parts. These include the plants and tendrils with bunches of flowers around on the rim arranged according to the traditional Hutterite, Haban triple composition; there may also be a central motive in the middle of the well of the dish (MNM 1973.10; MNM 1954.366. 1627; IMM 1956.390.1; IMM 19478; IMM 21814; MNM 1963.130; NM 51.31.517). A date and monogram may also be placed on the rim (Plate 6). A variation of this has two identical motives at the bottom and above them only a date or monogram (MNM 1954.345, F:A: 1728). In another variation a date, monogram or craft symbol is painted between the curve of two leaves in the band around on the rim $^{32}$ or the plant element proliferates to fill the whole width of the rim. Decorations in four parts (Plate 7). Four+four-part (MNM 1961.452; IMM 2945; IMM 6630; IMM 6631; NM 62.76.1), four+three-part pattern distribution (IMM 2912; IMM 2935), with the same motive repeated in the centre. The plants facing each other are identical. They grow out of the centre towards the edge of the rim, starting from the inflection point of the dish (IMM 6631; IMM 2898). In a variation of this arrangement the plants facing each other are identical and alternate with motives growing out from the centre and curving inwards from the outer edge of the rim (IMM 2945; IMM 2912). The four+four motive often emphasises a strong vertical articulation - e.g. lily of the valley, leafy branch (IMM 6631). Medallion arrangement. In a transitional type with a four+four medallion arrangement, where a curved frame is created around the elements of the four-part division with lines starting from the outside of the rim (IMM 2910; IMM 2945; IMM 2912). Medallion arrangement in the band around the rim (IMM 2910; IMM 1959.966) with 11, 14 medallions - a late type, found in two undated dishes and the one from 1770 (MNM 1954.344). Characteristic elements of the stock of patterns are flowers seen from above and the side (tulips, pomegranates, flowers in panicles, etc.), bunches of tendrils, upright flowering plants - lily of the valley, branch of pine or rosemary. Traditional Haban motives in addition to the plant ornamentations include geometrical double outline, wavy line, lace (pyramid of arches) motive. The date is placed on the rim in a wreath (MNM 1954.395), in an open wreath (IMM 16154), between two leafy branches (IMM 2911). Dot-and-circle motive and buildings are characteristic of the blue-and-white type, but they sometimes also appear on these vessels (IMM 2945, IMM 16.154; IMM 16154). In the late stock of motives triangular hatching, petal lines radiating from the centre of a flower only half of which is shown, and stylised plant motives of a new type appear (IMM 16154). Unusually, a dish dated 1728 (IMM 2931) ${ }^{33}$ has a single large motive, a stylised two-headed eagle fills the whole inside part of the vessel. So far we have found three dishes with craft symbols (NM 54.105.2, 1732, miner?), ${ }^{34}$ (IMM 2896, 1730, butcher), ${ }^{35}$ (IMM 2911. 1725. I.P. weaver). Numerous pieces are decorated with a monogram or double monogram. The latter were almost certainly ordered to mark weddings,

32 IMM 2896 1730, butcher; NM 54.105.2 AW 1732 http://public.neprajz.hu/neprajz.01.03. php?bm=1\&kv=8660280\&nks=1, 1732. Description by Mária Kresz - István Csupor, North-West Hungary.

33 http:/gyujtemeny.IMM.hu/gyujtemeny/tal-ketfeju-sas-alakjaval/2773, The dish was a gift from György Ráth in 1894. The description on the card localises it to the territory of Upper Hungary. 1728.

${ }^{34} \mathrm{http}$ ://public.neprajz.hu/neprajz.01.03.php?bm=1\&kv=8660280\&nks=1, North-western Hungary. Description by Mária Kresz - István Csupor.

${ }^{35} \mathrm{http}$ //gyujtemeny.imm.hu/gyujtemeny/tal-meszaros-cehjelvenyekkel/2285 
as is the case of the white dish dated 1734 (MNM 54.340) and decorated with the names of (Nemes és Bötsületes (Noble and Honest) Janos Vigh and Kata Krisanovics. The decoration of the wheel-thrown bodies of rotation, jugs and tankards is characterised by very large floral motives drawn with dynamic brush strokes. In some cases a plant with five flowers (MNM 1961.462) or a tendril with three flowers (IMM 2900) fills the whole side of the jug opposite the handle (Plate 8). The motive often extends beyond the double lines articulating the surface. In some cases the surface bordered by the traditional Haban lace-like pyramids of arches is crowded full of small plant motives in an attempt to fill the entire space (MNM 1954.393. 1729, Iohannes Termann). Pieces decorated with craft symbols (Plate 9), mainly miners'symbols, pieces with a name or monogram form a characteristic group within the elongated, oval-shaped, melon-bellied large jugs. So far we know of nine such blue vessels. Large jugs with miners' symbols: 1724, (...s? ) Luptak, $30 \mathrm{~cm}$, Coll. Lessner; 1725, MAR: SHA: in a medallion, MNM 1954.445; 1726, Georgius Barla, IMM 2925; ${ }^{36} 1728$, Hanzo Mezibrocki - in medallion, Central Slovakian Museum, Besztercebánya, no. 802; 1729, Gerrium Balz. Prague, Národní Muzeum $59.07131 \mathrm{~cm}$; 1729, Johanes Woltar, Gyulafehérvár, Batthyány Library no. 20682; 1735, G. R. monogram on the neck, IMM 59.224837. A blue jug made for Mihael Kohut with the symbols of the weavers' guild is dated 1736 (IMM 21.800, $32 \mathrm{~cm}$, collection of Vince Wartha). A white, miner's jug dated 1756 is published by Kalesny (KAlESNy 1981: 221. item no. 344. Stredoslovenské múzeum v Banskej Bystrici Inv. n. 398.), other miners' vessels are published by Pišutová (PIšUtovÁ 2014). We measured five of these (MNM 1954.445; IMM 59.2248; IMM 2925, Gyulafehérvár, Batthyáneum no. 20682; IMM 21800). In most cases the space between the double line painted around the lower third of the body and at the beginning of the neck is entirely covered with a decoration of miners' symbols framed with a wreath: miner's hammer, chisel, leather apron (HORVÁTH - KRISZTINKOVICH 2005: 236-237; SzEMÁn 2012: 49). The miner entered the mine by sliding down the head slope on the leather, and if necessary sat on the apron to work. It also had a symbolic meaning as the symbol of the miners' honour (SzEMÁN 2012: 49). In addition to the large floral motive, four of the pieces have at the bottom a row of arches arranged into pyramids 3, 4 or 5 levels high, but motives of another kind also appear, such as a chevron motive all round the body (MNM 1954.445) or the use of three dots as decoration (Prague NM 59.071).

\section{WHERE WERE THE PIECES OF THE "MINING TOWN WORKSHOP” MADE?}

The identifications attached to vessels in various public and private collections and the data on description cards give various places as the place where the piece concerned was made. The literature mentions Alvinc, the Transylvanian territory, and the vicinity of Zólyom (Zvolen, Slovakia) and Besztercebánya. The Transylvanian researchers published pieces belonging to this style and found in museums in Romania and in Czech and Slo-

36 http://gyujtemeny.IMM.hu/gyujtemeny/kanna-banyaszjelvennyel-georgius-bartha-1726-felirattal/2289, Upper Hungary, 1726, with further literature.

37 http:/gyujtemeny.IMM.hu/gyujtemeny/kanna-banyaszjelvennyel/2306, 1735, Upper Hungary. 
vakian museums as being from Alvinc (Bunta 1973: 93, no. 18B; RoșCA - KLusch 2010: Fig. 542), Kybalova places them in Slovakia (KyBAlova - Novotna 1981: 90, 247). Béla Krisztinkovich, ${ }^{38}$ and later the co-authors, Krisztinkovich and Horváth, group mainly only blue vessels into this style and in their publications give the place of production as Northern Hungary, the mining towns, possibly in the vicinity of Selmecbánya (Banská Štiavnica, Slovakia), Körmöcbánya (Kremnica, Slovakia), or perhaps Besztercebánya (HoRvÁTH - KRISZTINKOVICH 2005: 236-237, 245-246). They mention that Jürgen Fischer defined the large jug with miners' symbols, the monogram M:P: and the date 1731 as being from Alvinc, but by 1731 the Haban settlement in Alvinc was already very weak, its residents had moved away or assimilated into the Transylvanian Saxon population. The new wave of settlers arriving from Austria and the settlement's new flourishing can be observed only from 1755 . The authors consider it likely that the master was active in a Haban settlement, by then converted to Catholicism, in the territory of the former Northern Hungary, today Slovakia. In the opinion of Mária Krisztinkovich Sárospatak is another possible location. While it is true that the Haban settlement there disintegrated around 1680, numerous potters were active there in the $18^{\text {th }}$ century, among others the Wipf family. Gabriella Vida considers that the area of the former Zólyom county is the most likely place of production of the blue- and perhaps also together with them the white-glazed ceramics belonging to a similar style (VIDA 2008: 165, 195). In her opinion the pieces in the Museum of Ethnography classified here almost without exception entered the museum from this area, mainly from the vicinity of Besztercebánya. She considers that these pieces were produced in Besztercebánya, Zólyom or the smaller mining towns along the upper reaches of the River Garam. "They suggest masters with a good sense of style but more limited manual skills, their products are slightly more robust than the classical Haban vessels. They were made between 1720 and 1750." (VIDA 2008: 54, 105) A number of authors consider them to be the first folk-style variants of Haban ceramics. János Szendrei mentions that a Haban potter called Messerschmidt also worked in Libetbánya (L'ubietova, Slovakia) (SzENDREI 1889: 174). Gabriella Vida cites this information in her article in the present volume and examines this style and its connections in more detail, as well as the question of Libetbánya. She recently found in the papers of Mária Kresz the notebook in which she recorded the conversations she had with Heřman Landsfeld in late 1959 and early 1960. ${ }^{39}$ According to these notes Landsfeld did not regard the dark blue vessels as Haban pieces, in his opinion they are the work of a Slovak master, Haban copies, perhaps made in the area of Besztercebánya. This opinion is also represented today by the archaeologist Jiří Pajer. ${ }^{40}$ Pišutová, partly following the work of Drugová, places the area in which the workshop operated in Besztercebánya, or Libetbánya and/or Tájó (Tajov, Slovakia) (Pıšutová 2014: 125, 128). It can be seen that there are still many question marks and much uncertainty. What do we know? It would appear that the production of vessels belonging to this workshop circle began at the end of the $17^{\text {th }}$ century and the tradition was passed on right up to the 1770 s. This means that the

${ }^{38}$ KriszTinKOVICH 1962: 40. Group of dishes with a blue ground glaze, all of which were produced in a period of a few years prior to 1734, and evidently the work of a single craftsman. He operated near the mining centre of Besztercebánya.

${ }^{39}$ A Néprajzi Múzeum Ethnológiai Archívuma 8/20.

${ }^{40}$ Personal communication with Jiří Pajer. 
beginning of the workshop's activity must be put some 25 years earlier, changing the date generally accepted in the literature. The blue glaze on every piece measured so far that can be classified in this group on the basis of stylistic considerations has been found to contain uranium. It is possible that for around 70 years they obtained the cobalt needed for the blue colour from the same source(?). In the case of the blue glazes containing uranium, the stove from Liptónádasd can probably be localised with greatest certainty, it was probably made in the area of the mining towns of Lower Hungary. Based on the statistical analysis of the XRF data the stove from Liptónádasd was classified among the vessels containing uranium made in the 1720s. (XRF data were evaluated by the Statistica software (version 11 and 12) using cluster, factor, and principal component analysis.) The workshops making stove tiles are typically conservative, the motives and tile moulds were used and passed on for decades. Consideration could be given to changing the date of the Liptónádasd stove to the early $18^{\text {th }}$ century. (However, the glaze on the tiles of the stove from Besztercebánya that were probably made earlier, probably also locally, does not (?) contain uranium, which suggests the need for caution.) The vessels that can be considered as belonging to this workshop are known from various places, many have been preserved in private collections. There is very little information on the places where these vessels were used. The dish dated 1730 (NM 13138) was collected from Gyetva (Detva, Slovakia) ${ }^{41}$ in Zólyom County. The dish (MNM 1963. 130) dated 1714 was used as a communion plate in the Calvinist church of Szentkirályszabadja, Veszprém County. The jug preserved in the Batthyaneum in Gyulafehérvár may have been used in Transylvania. According to our present knowledge, the greatest number of these objects are preserved in public museum collections in Hungary. A number of conclusions can be drawn from the shape of the vessels, their decoration, and the decoration on the large jugs with miners' symbols. The circle of buyers changed in social composition and grew wider. As a consequence there was a demand for more ceramics. Both the technology and the style changed. The decoration became more roughly drawn and often crowded. On the basis of their material, shape and manner of painting the miners' jugs that have survived in various places (in Hungarian, Slovakian, Czech, Austrian and Romanian collections) can be linked to a single workshop; so far we know pieces that can be dated between 1724 and 1735. The workshop must probably have been close to the clients, in the vicinity of a mining town; perhaps in a place where cobalt was also mined nearby making it easier to obtain the cobalt pigment. A very small quantity of cobalt pigment is sufficient to give a strong blue colour. It was available commercially, and so it also reached places at a considerable distance from the cobalt mines and the places where the pigment was made.

\section{COBALT MINING IN HUNGARY}

According to $18^{\text {th }}$ century sources cobalt suitable for the production of pigment needed for blue paint was mined in Hungary. A decree issued in 1746 - dated $1^{\text {st }}$ November 1746 - at the instruction of the chief director of mines ordered that no permits were to

\footnotetext{
${ }^{41}$ http://public.neprajz.hu/neprajz.01.03.php?bm=1\&kv=8660280\&nks=1, 1730 by Gabriella Vida.
} 
be issued for the extraction of cobalt, as Her Majesty reserved the right to process cobalt into pigment (PÉCH 1884-1887: III./3 1051; IzSó 2009: 14). This probably applied to Szomolnok (now Smolník, Slovakia). The question arises whether earlier others also had the right to process cobalt. Cobalt mining probably started earlier, as well as the production of the raw material for pigment (zaffre, smalte). But we have not yet found any reference to this. The Ore Mountains on the border between Bohemia and Saxony were the most important sources of cobalt in Europe; cobalt pigment used to colour ceramic glazes and glass was exported throughout the world from here as early as the $12^{\text {th }}$ century (GRATUZE et al. 1996: 80; ZuCCHIATI et al. 2006: 132-133). The mining of cobalt was closely linked to silver mining; the so-called five-element veins (Ni-Co-As-Ag-Bi-U) were mined in the Saxon-Bohemian Ore Mountains (KISSIN 1992). Friedrich Kapf (1759-1797), a German mineralogist in Breslau (Wrocław, Poland), wrote about the deposits in Hungary and elsewhere in Europe, as well as on the mining of cobalt and the various ways of making the pigment (KAPF 1792). Cobalt deposits were found in Hungary in the following places: Puganz - also known as Bakabánya, Pukanec, in Hont County (Pukanec, Slovakia) - was one of the 10 major mining towns in Lower Hungary in the vicinity of Besztercebánya and Selmecbánya. In the Szepesség region of Upper Hungary, Schmöllnitz (Szomolnok, Kassa district, Slovakia) and Dobschau (Dobsina, Gömör County, Slovakia) were recorded as places where cobalt was mined. The Hungarian cobalt from Schmöllnitz/Szomolnok was made into pigment in Klodnitz, Austria (KAPF 1792: 74) in the $18^{\text {th }}$ century. Klodnitz (Kłodnica) is now in Poland, between Kraków and Wrocław. In the Banat region cobalt was found in Oraviza (or Oravicabánya, Orawitz, Krassó-Szörény County, now Oravita, Romania). With the exception of Oravica, the other places had been mined for silver from the Middle Ages (KAPF 1792: 41). Where could the cobalt ore containing uranium have been mined? There are many such sources in the Bohemian Ore Mountains, among them Joachimstal. Dobsina is a five-element vein type ore deposit (KISSIN 1992), but it was known as a source of cobalt from the 1780s, we have data on the mining of cobalt for use as pigment from that time (RozLozsnik 1937). The Transylvanian researchers (BunTA 1973; RoșCA - KLuSch 2010) regard the Transylvanian mountains closer to Alvinc, the Hátszeg, Zalatna, Rézbánya areas, as the source of the cobalt used there.

\section{CONCLUSION}

Right from the start the products of the Hutterite and later the Haban workshops included blue-glazed vessels and from the second half of the $17^{\text {th }}$ century there was an increase in the number of pieces with a lighter and darker blue glaze. The vessels examined show that in making the blue glaze with cobalt pigment various amounts of tin were almost always used in the glaze in the $17^{\text {th }}$ and $18^{\text {th }}$ centuries (BAJNóczi et al. 2015). In some of the pieces the XRF measurements also found uranium together with cobalt in the blue glaze and in the blue decoration on the white glaze. On the basis of considerations of style, periodisation and place of production, the vessels with uranium-bearing blue glaze can be classified into a number of groups. We can conclude with a high degree of certainty from the archaeological finds that blue vessels covered with a cobalt glaze containing uranium 
were made in the second half of the $17^{\text {th }}$ century in Sárospatak and Alvinc, as well as in Szobotist. After the disintegration of the Hutterite settlements based on collective payment of taxes and common ownership of assets (1685/86), a workshop of Haban origin and cultivating Haban traditions operated from the end of the $17^{\text {th }}$ century in North-Western Hungary (now Western Slovakia) further away from the Haban settlements, probably in the vicinity of the mining towns in Lower Hungary, near Besztecebánya, on the upper reach of the River Garam. On the basis of production technique, stylistic considerations and material examinations, the vessels produced here form a clearly distinct group. The workshop's most productive period was in the 1720 s to 1730 s, but its style lived on for decades after that. The Haban system of composition, the transformation of motives and the shift of the style towards a folk-like style can be clearly observed in this group of objects.

\section{ACKNOWLEDGEMENTS}

We thank Gabriella Balla, Katalin Csontos, Kornélia Hajtó and Diána Radványi (Museum of Applied Arts, Budapest), Gabriella Vida (Museum of Ethnography, Budapest), Eszter Kovács, Anikó Tóth (Budapest History Museum), Edit Tamás and István Ringer (Rákóczi Museum of the Hungarian National Museum, Sárospatak), Eszter Eperjesi Pocsainé (Scientific Collections of the Reformed College of Sárospatak), Melinda Mitu (Transylvanian National Historical Museum, Kolozsvár), Tekla Tötszegi (Transylvanian Museum of Ethnography, Kolozsvár), Gábor Teleky and Enikő Hegedüs (Collection of the Roman Catholic Episcopacy of Gyulafehérvár), Doina Biró Hendre (Batthyaneum, Gyulafehérvár), Botond Gudor (Nagyenyed County of Reformed Church), Karla Roşca (ASTRA Museum, Sibiu, Romania), Claudia Peschel-Wacha (Museum of Folk Life and Folk Art, Vienna), Jiří Pajer (Czech Republic) for their great help. This study was supported by the Hungarian Scientific Research Fund (OTKA K81201, K81213 and K81133) and the János Bolyai Research Scholarship of the Hungarian Academy of Sciences (granted to B. Bajnóczi).

\section{LITERATURE}

BAJnócZi Bernadett - MAY Zoltán - Ridovics Anna - Szabó Máté - NAGY Géza - Tóth Mária

2015: The Tin Content of the Blue-Glazed Hutterite and Haban Ceramics - Implications for the production technology based on the results of the handheld XRF and EMPA analyses. Acta Ethnographica Hungarica 60/2. 517-534.

BALLA Gabriella

1988: Habán kerámiák tárgyleírásai [Descriptions of Haban Ceramics]. In: Reneszánsz és manierizmus. Az európai iparmüvészet korszakai [Renaissance and Mannerism. Periods in European Applied Arts]. Ed.: PÉTER Márta: Iparmúvészeti Múzeum, Budapest. 146-154.

Blake, Hugo

1981: Pottery Exported from Northwest Italy between 1450 and 1830: Savona, Albisola, Genoa, Pisa, and Montelupo. In: Archaeology and Italian Society. Prehistoric, Roman and Medieval Studies. Eds: BARker, Graeme - Hodges, Richard. Papers in Italian Archaeology II. BAR International Series 102. 99-124. 
Bunta Magda

1973: Az erdélyi habán kerámia [Haban Ceramics in Transylvania]. Bucharest, Kriterion.

DÉTSHY Mihály

1972: Adalékok a sárospataki újkeresztények (habánok) történetéhez [New Data on the History of the Anabaptists (Habans) of Sárospatak]. A Hermann Ottó Múzeum Évkönyvei 11. 124-135.

EMŐDI Tamás

2009: Habán kályha [Haban Stove]. In: A gyulafehérvári római katolikus székesegyház és püspöki palota. Régészetés történelem. / Catedrala Romano-Catolica si Palatul Episcopal Al din Alba Iulia. Archeologie si istorie, The Roman Catholic Cathedral and the Episcopal Palace in Alba Iulia. Archaeology and History. Catalogue. Ed.: Daniela Marcu Istrate. Alba Iulia. 150.

2012: A gyulafehérvári fejedelmi palota rekonstruált habán kályhája [Reconstructed Haban Stove from the Episcopal Palace in Alba Iulia]. In: Élő múltunk. A gyulafehérvári Szent Mihály székesegyház és érseki palota [Our Living Past. The Saint Michael's Cathedral and Episcopal Palace of Alba Iulia]. Verbum, Kolozsvár. 171-175.

Fabri, B. - Gualtieri, S. - Lega, A. M.

2001: Application Technology and Composition of the Glazes of the Renaissance "Italo-Moresque and Diluted "Zaffera" majolica manufactured in Faenza (Italy). 32nd International Symposium on Archeometry, May 15-19, Mexico. 1-4.

Gratuze, B. - Soulier, I. - Blet, M. - Vallauri, L.

1996: De l'origine du cobalt: du verre à la céramique. Revue d'Archéométrie 20, 77-94.

Gyurica Anna

1992: Reneszánsz kályhacsempék Északkelet-Magyarországról [Renaissance Stove Tiles from North-East Hungary]. Borsodi kismonográfiák, 37. Miskolc, Herman Ottó Múzeum.

Horváth, J. Eugene - Krisztinkovich, Maria

2005: A History of Haban Ceramics. Private View. Canada, Vancouver.

Izsó István

2009: A montanisztika magyarországi történetének levéltári forrásai [Archival Sources on the History of Mining Studies in Hungary]. II. Központi Bányászati Múzeum Közleményei 7. Sopron.

JERVIS JONES, William

1841/2013: German Colour Terms: A study in their historical evolution from earliest time to the present. Studies in the History of the Language Sciences 119.

KAPF, Friedrich

1792: Beytrage zur Geschichte des Kobolts, Koboltbergbaues und der Blaufarbenwerke (Breslau).

KATONA Imre

1969: Szemelvények a Batthyány-Levéltár Anabaptista emlékeiből [Extracts from the Anabaptist Records in the Batthyány Archive]. I. In: Vasi Szemle 3.

1974: A habán kerámia Magyarországon [Haban Ceramics in Hungary]. Képzőmúvészeti Alap Kiadóvállalata, Budapest.

2001: Habánok Magyarországon [Habans in Hungary]. Gesta Könyvkiadó, Budapest.

Kiss Erika

2008: Tárgyleírás. Ötvösművek a 16-17. századi Magyarországon. [16 $6^{\text {th }}-17^{\text {th }}$ century metalware] In: Mátyás király öröksége. Későreneszánsz müvészet Magyarországon. (16-17. század I-II.) Eds.: Miкó Árpád - Verö Mária, Budapest, Magyar Nemzeti Galéria, I. 330-331, II. 99-114.

Kissin, S. A.

1992: Five-element (Ni-Co-As-Ag-Bi) veins. In: Geoscience Canada 19, 113-124.

Krisztinkovich Béla

1962: Haban Pottery. Budapest, Corvina Press

Kybalová Jana - NovotnÁ, Jarmila

1981: Habánska fajáns 1590 - 1730 [Haban Faience, exhibition catalogue]. Praha, Uměleckoprůmyslové museum.

Marcu Istrate, Daniela

2009: Tárgyleírás [Object Description]. In: A gyulafehérvári római katolikus székesegyház és püspöki palota. Régészet és történelem. / Catedrala Romano-Catolica si Palatul Episcopal Al din Alba Iulia. 
Archeologie si istorie, The Roman Catholic Cathedral and the Episcopal Palace in Alba Iulia. Archaelogy and History. Catalogue. Ed.: Daniela Marcu Istrate. Alba Iulia. 147.

PAJER, Jiří

2001: Novokřtěnské fajánse ze Strachotína. Regionální Muzeum, Mikulov.

2006: Studie o Novokřtěnich. Nakladatelství Etnos, Strážnice.

2011: Anabaptist Faience from Moravia 1593-1620. Catalogue of documents from institutional and private collections. Ethnos Publishing, Strážnice.

PÉCH Antal

1884-1887: Alsó-Magyarország bányamívelésének története [History of Mining in Lower Hungary]. Selmecbánya-Budapest. III./3.

Picolpasso, Cipriano

2007: The Three Books of the Potter's Art (I tre libri dell'arte del vasaio). Facsimile of the manuscript in the Victoria and Albert Museum. Translated and introduced by Ronald Lightbrow and Alan CaigerSmith. London, 2nd edition, Editions La Revue de la céramique et du verre.

PIŠUtovÁ, Irena

2014: Nové poznatky o habánoch a ich tvorbe na strednom Slovensku v 18. storičí. In: Zbornik Slovenského Národného Múzea v Martine, Etnografia 55, Ročnik CVIII, 113-136.

Pocsainé EperJesi Eszter

2010: Habán kerámiák a sárospataki Református Kollégium Múzeumában [Haban Ceramics in the Museum of the Sárospatak Calvinist College]. In: Történet-muzeológia. Tanulmányok a múzeumi tudományok köréböl a 60 éves Veres László tiszteletére [History-Museology. Festschrift for László Veres]. Eds.: Gyulai Éva - Viga Gyula. Miskolc. 223-219.

RadVÁNYi Diána - RÉTI László

(s.d. 2011): A habánok kerámiamüvészete. A Kárpát-medence kerámiamüvészete IV. kötet [Ceramic Art of Habans. 4th volume of the book series Ceramic Art of the Carpathian Basin]. Budapest, Novella Könyvkiadó.

RADVÁNYi Diána

2013: Fayencekachelöfen der Habaner, Ofenkacheln und ihre Rekonstruktionen in der Sammlung des Kunstgewerbemuseums zu Budapest. Ars Decorativa 29. Ed.: Ágnes PréKopa. 57-70.

Ravanella Guidotti, Carmen

1998: Thesaurus di opere della tradizione di Faenza nelle raccolte del Museo Internazionale delle Ceramiche in Faenza. Faenza, Agenzia Polo Ceramico.

Ridovics Anna

2002: A Magyar Nemzeti Múzeum habán kerámiái a 17-18. századból [Pieces of Habán Pottery in the Hungarian National Museum]. Folia Historica 23/1, 67-87 (English summary: pp. 85-87).

2008: A habán kerámia a 17. században [Haban Ceramics in the $17^{\text {th }}$ Century]. In: Mátyás király öröksége - Késö reneszánsz müvészet Magyarországon [The Legacy of King Matthias. Late Renaissance Art in Hungary $\left(16^{\text {th }}-17^{\text {th }}\right.$ century)]. II. Eds.: Mikó Árpád - Verö Mária.

2013: Umeleckohistorický a archeometrický výskum habánskej keramiky vstátnnych a súkromných zbierkach v Mad’arsku. In Agáta Petrakovičova (Ed.): Habani a Habánska keramika. Zbornik z medzinárodného odborného seminára, konanéha 3. septembra 2011 v Modre. Slávnost' hliny Keramická Modra 2011. III. Ročnik. SNM Múzeum L’udovita Štúra v Modre. Modor. 68-78.

RINGER István

2014: Uradalmi és mezövárosi mühelyek a 17. századi Sárospatakon. A régészeti kutatások eredményei [Workshops on Estates and in Market Towns in $17^{\text {th }}$ Century Sárospatak. Results of Archaeological Research]. Doctoral dissertation, Budapest.

2015: Archaeological Excavation on the Haban Colony Site at Sárospatak. Acta Ethnographica Hungarica $60 / 2,419-444$.

RoșcA, Karla - Kuusch, Horst

2010: Ceramica de breaslă, habana şi manufacturieră din Transilvania. Sibiu, Honterus.

Rozlozsnik Pál

1937: Dobsina bányászata [Mining in Dobsina]. In: A 600 éves Dobsina. 1326-1926. Emlékkönyv Dobsina bányaváros alapításának 600 éves évfordulójára [The 600-Year-Old Dobsina. Memorial book for the 600th anniversary of the fundation of Dobsina mining town]. Ed.: GÖMÖRY Árpád. 67-75. 
Ruffini, A. - Gualtieri, S. - Fabbri, B.

2005: Comparison between Renaissance "Berettino" Glazes from some Ceramic Centres in Northern Italy. In: H. KARs \& E. Burke (Eds.): Proceedings of the 33rd International Symposium on Archaeometry, 22-26 April 2002, Amsterdam; Geoarchaeological and Bioarchaeological Studies 3, Inst. for Geo- and Bioarchaeology, Vrije Universiteit, Amsterdam. 249-252.

SzÁDECZKy Béla

1911: I. Apafi Mihály fejedelem udvartartása [The Court of Prince Mihály Apafi]. vol. I. Bornemisza Anna Gazdasági Naplói (1667-1690) [Economic Diaries of Anna Bornemisza (1667-1690)]. Magyar Tudományos Akadémia, Budapest.

SzeBEni Olivér

1998: Anabaptisták [Anabaptists]. Magyarországi Baptista Egyház, Budapest.

SzEmÁn Attila

2012: A farbőr mint bányásszimbólum [The Miners’ Apron as a Miners' Symbol]. Bányászattörténeti közlemények. 39-63.

SzENDREI János

1889: A habánok története Magyarországon és a habán majolika [History of the Habans in Hungary and Haban Maiolica]. Müvészi Ipar 1889. 174.

TITE, M. S.

2009: The Production Technology of Italian Maiolica: A Reassessment. Journal of Archaeological Science 36, 2065-2080.

Zucchiatti, A. - Bouquillon, A. - Katona, I. - D’alessandro, A.

2006: The Della Robbia Blue: A Case Study for the Use of Cobalt Pigments in Ceramics during the Italian Renaissance. Archaeometry 48, 131-152.

VIDA Gabriella

2008a: Kályhacsempék [Stove Tiles]; Habán fajanszok [Haban Faience]. In: Legendás lények, varázslatos virágok - a közkedvelt reneszánsz [Legendary Beings, Enchanting Flowers - the Renaissance We All Know and Love]. Ed.: FeJős Zoltán, Budapest, Néprajzi Múzeum. 56-93, 164-166.

2015: The Budapest Museum of Ethnography's Haban Ceramics. Acta Ethnographica Hungarica 60/2, $305-321$. 


\section{Plate 1}

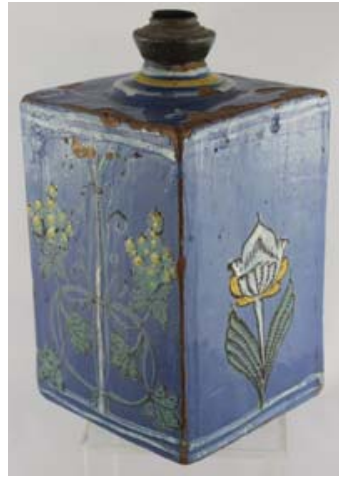

Bottle, 1696. Inv. n. KNM A 2314

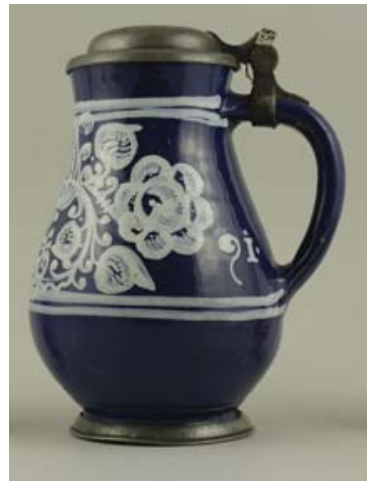

Small pear-shaped jug, 1691. Inv. n. IMM 2885

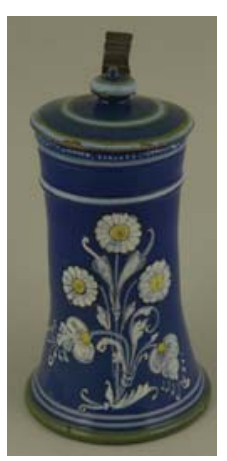

Tankard, around 1660-70. Inv. n. IMM 2871

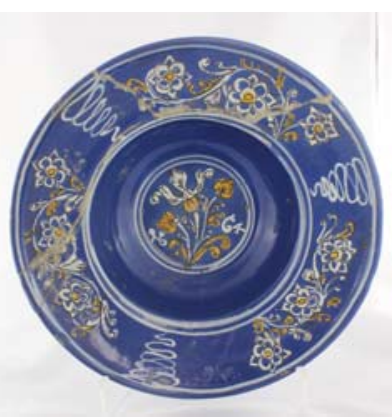

Dish, 1664. Inv. n. KNM A 1566

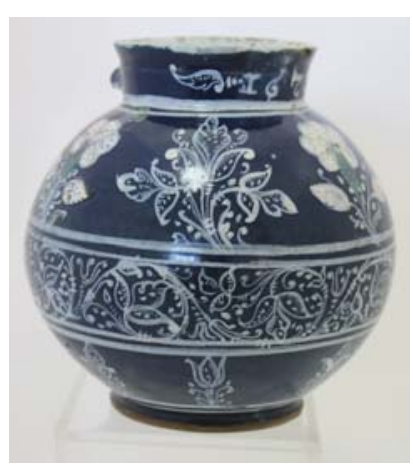

Round-bellied jug, 1672. Inv. n. KETM F 79

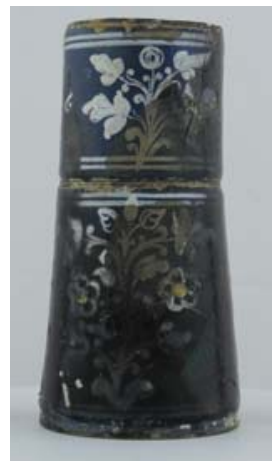

Tankard, 1651(?). Inv. n. MNM 1961. 3330

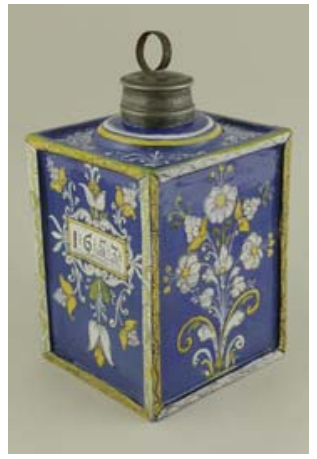

Bottle, 1653. Inv. n. IMM 2845

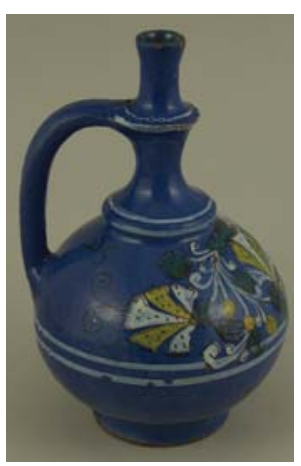

Jug, 1695. Inv. n. IMM 2873

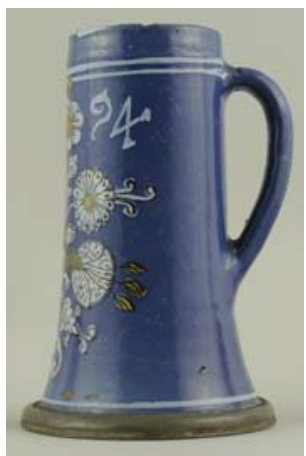

Tankard, 1694. Inv. n. IMM 74.55.1 
Plate 2

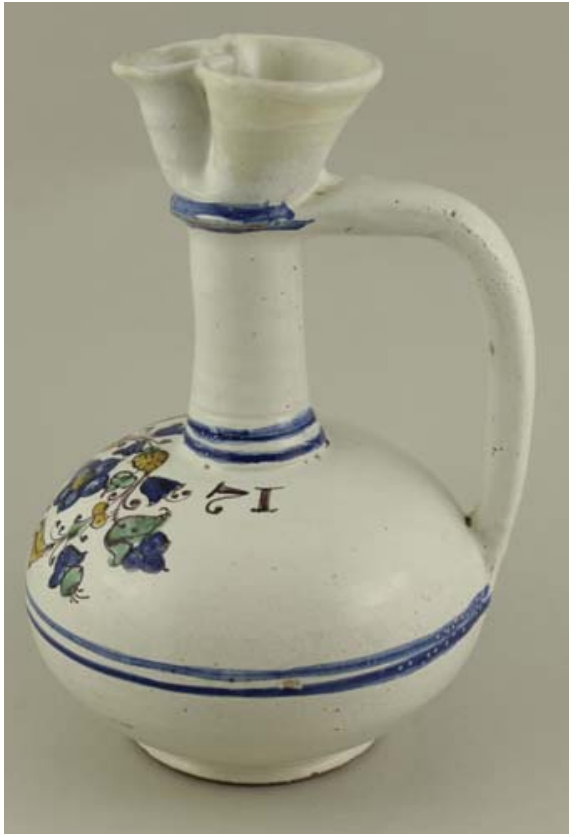

Jug with strainer. Inv. n. IMM 14.2844

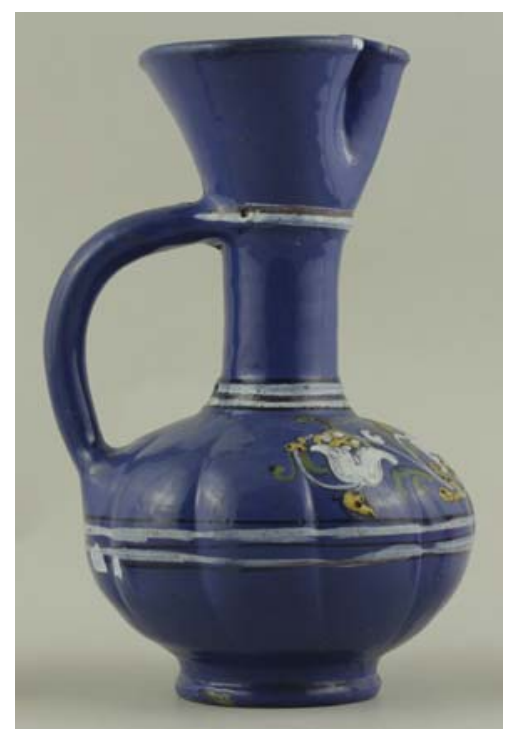

Jug with strainer, 1671. Inv. n. IMM 2866

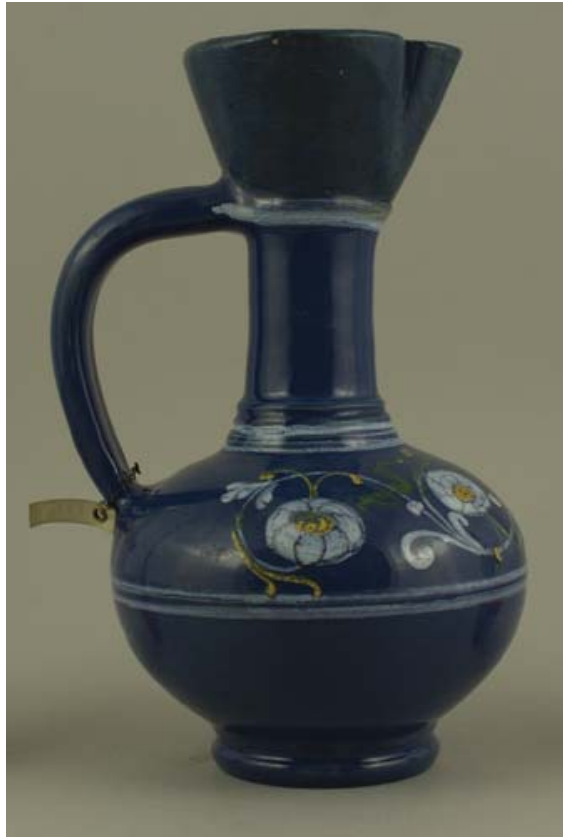

Jug with strainer. Inv. n. IMM 14.276

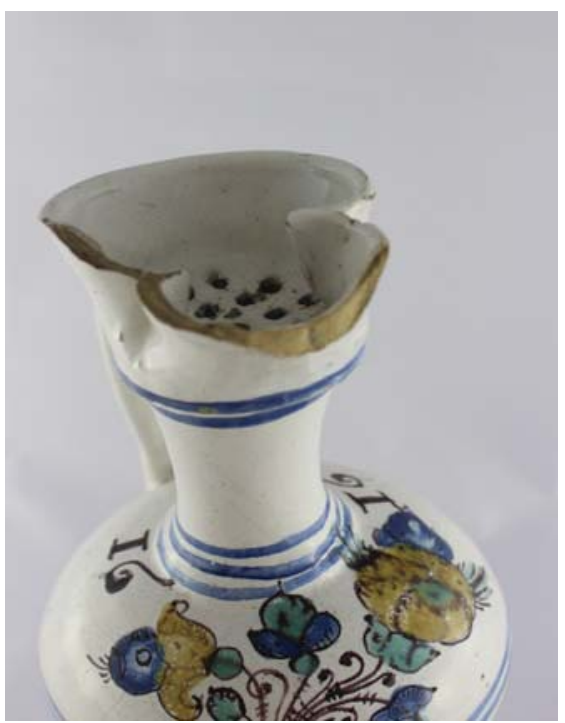

Jug with strainer, with faulty date, 1661 . Inv. n. KNM A 2317 


\section{Plate 3}

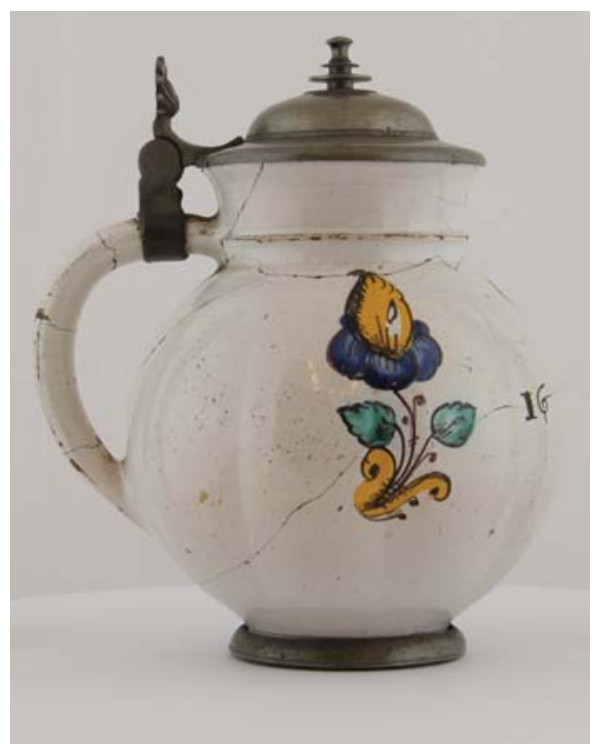

Round-bellied, fluted jug, 1655. Inv. n. MNM 1954.408

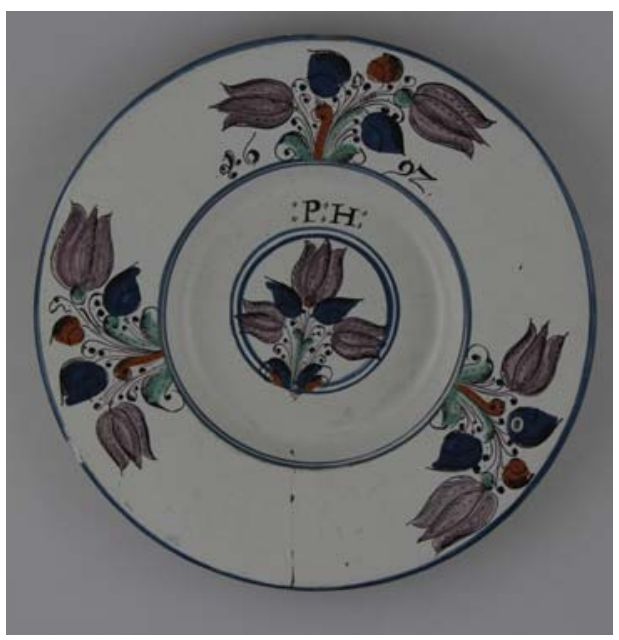

Dish, 1692. Inv. n. MNM 1954.436

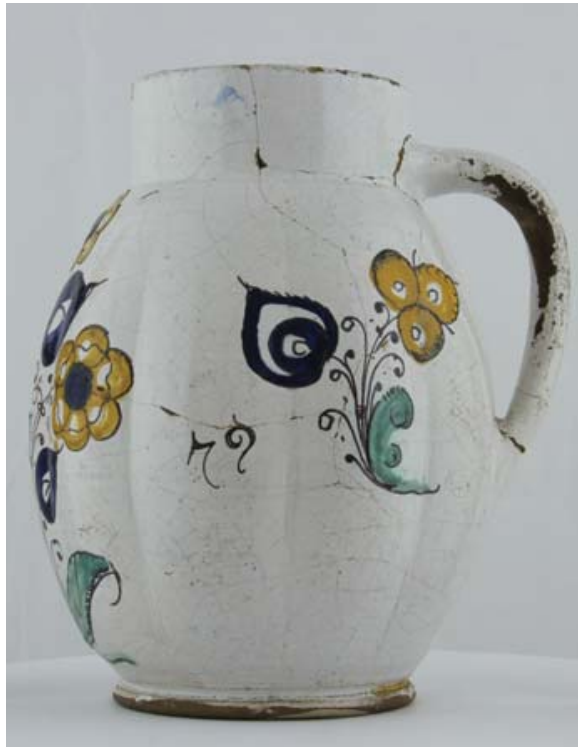

Oval-shaped, fluted jug, 1679. Inv. n. MNM 1961.404

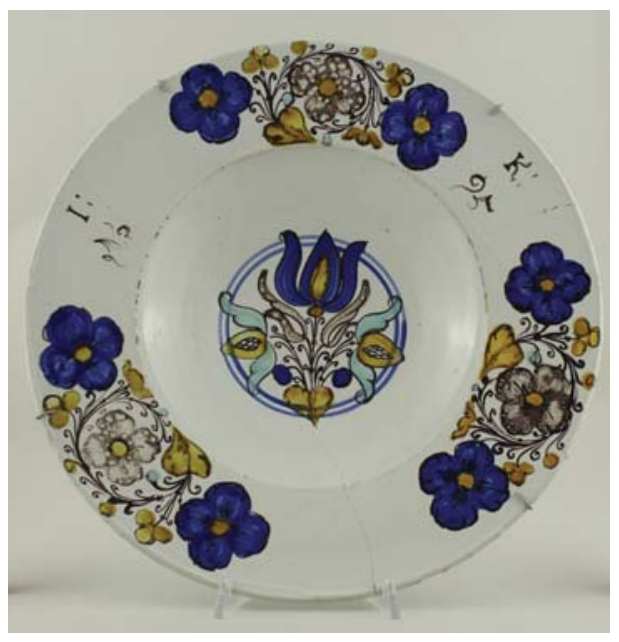

Dish, 1695.

Inv. n. IMM 21814 


\section{Plate 4}
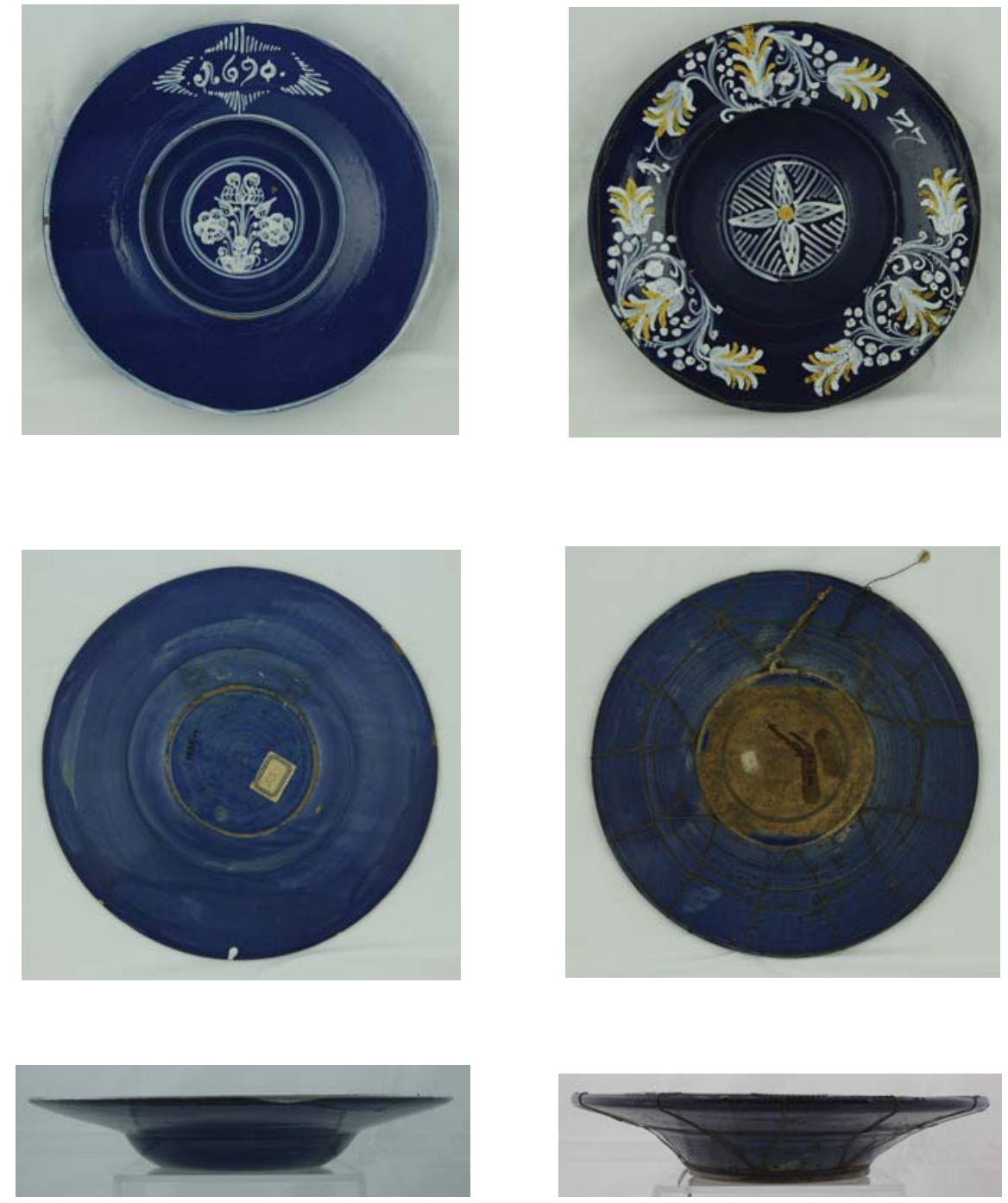

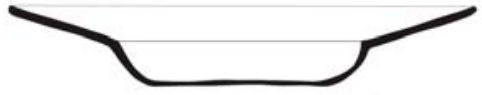

Dish, 1690.

Inv. n. MNM 1885.11

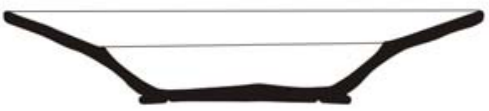

Dish, 1727.

Inv. n. MNM 1954.336 


\section{Plate 5}

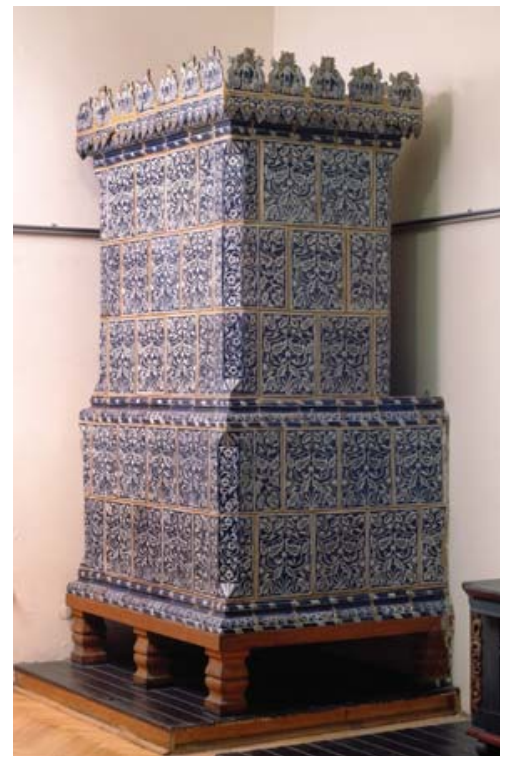

Stove from Liptónádasd, late $17^{\text {th }}$-early $18^{\text {th }} \mathrm{c}$. Inv. n. MNM 1927.63

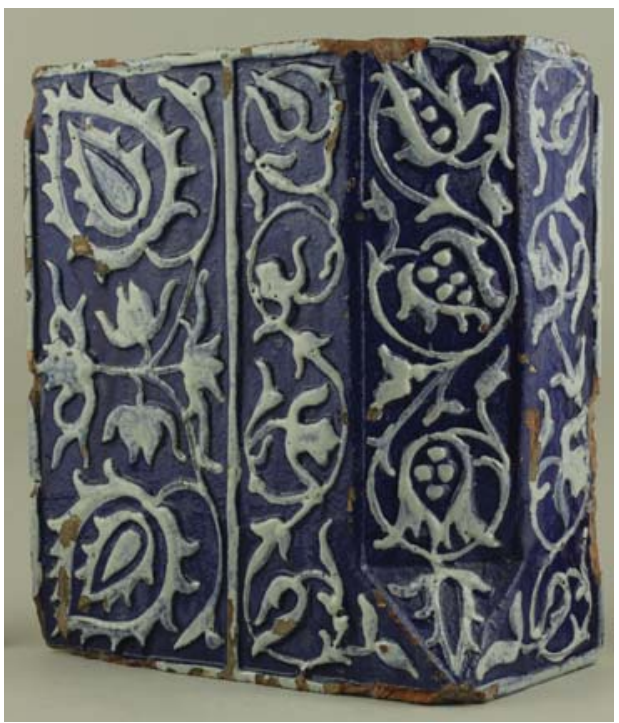

Stove tile.

Inv. n. IMM 52.3762.1

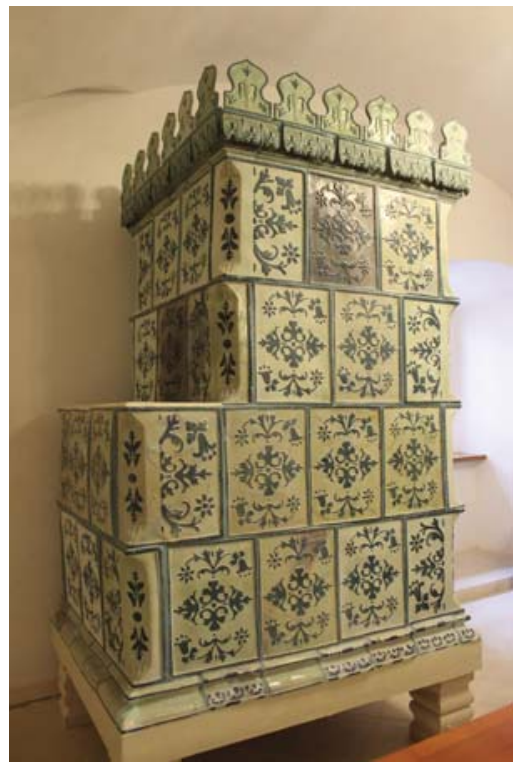

Stove from Gyulafehérvár, 1666-1687

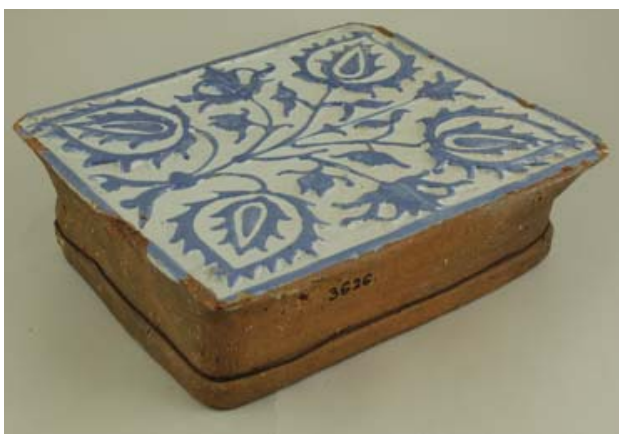

Stove tile.

Inv. n. IMM 3626 
Plate 6

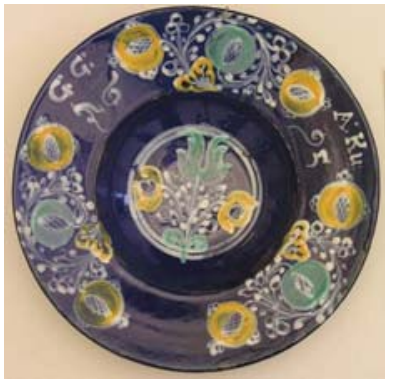

Dish, 1695. Inv. n. MNM 1973.10

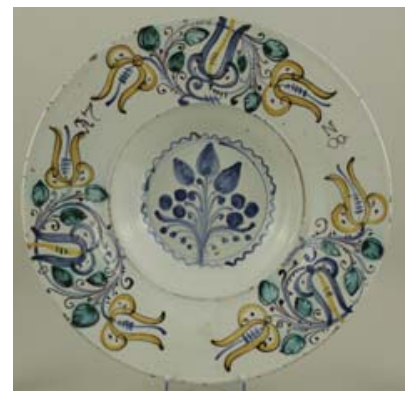

Dish, 1728. Inv. n. IMM 2899

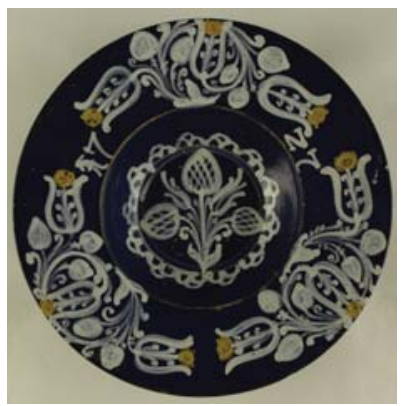

Dish, 1727. Inv. n. NM 51.33.234

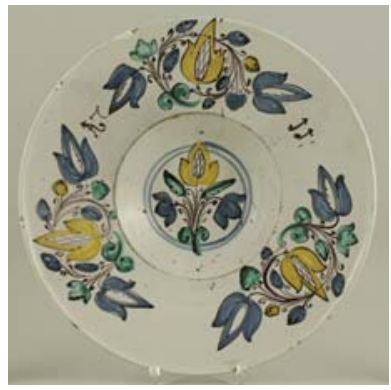

Dish, 1711. Inv. n. IMM 2732

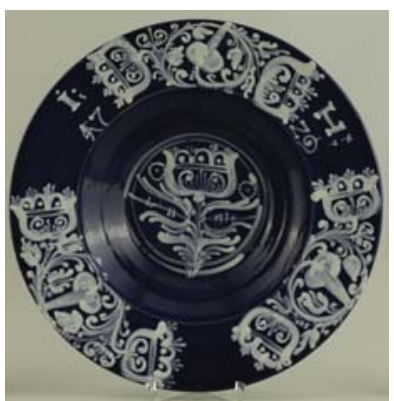

Dish, 1729. Inv. n. IMM 19478

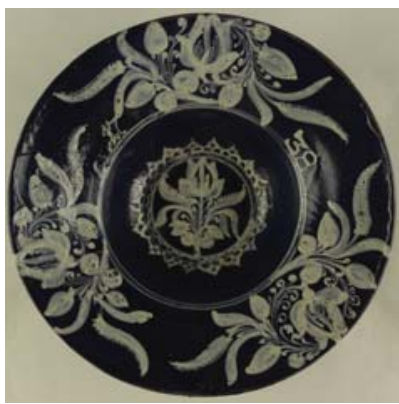

Dish, 1738. Inv. n. NM 51.33.235

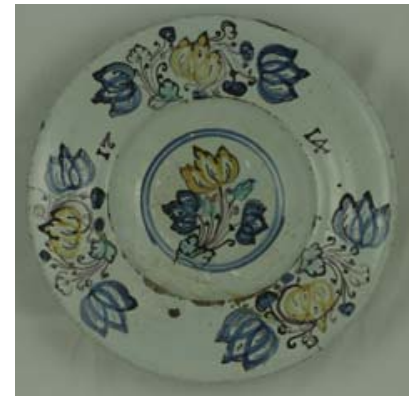

Dish, 1714. Inv. n. IMM 1963.130

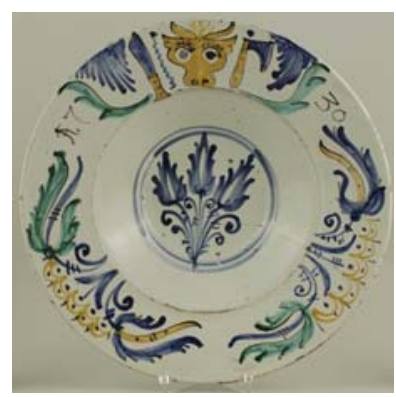

Dish, 1730. Inv. n. MNM 2896

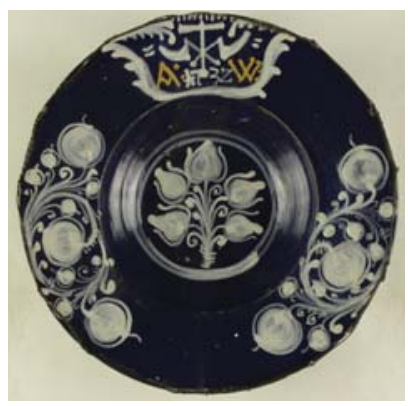

Dish, 1732. Inv. n. NM 54.105.1 
Plate 7

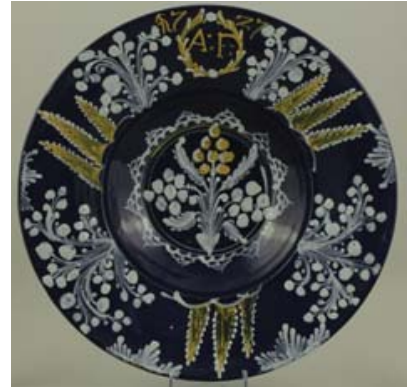

Dish, 1727. Inv. n. MNM 2935

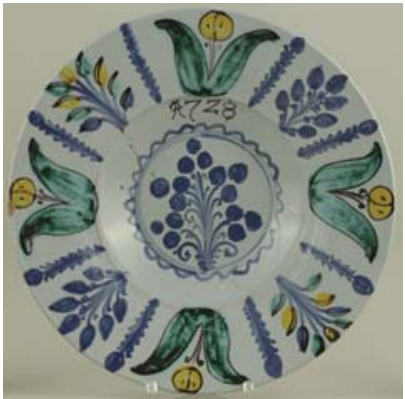

Dish, 1728. Inv. n. IMM 6630

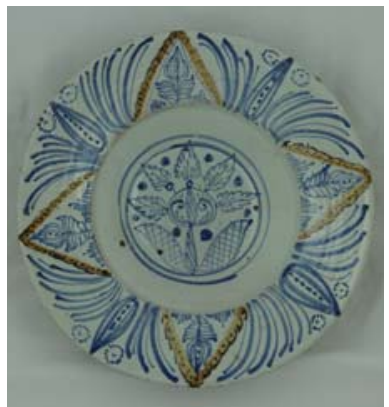

Dish, s.d. Inv. n. IMM 1961.452

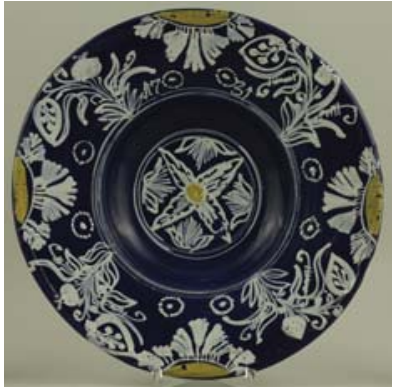

Dish, 1731. Inv. n. IMM 2945

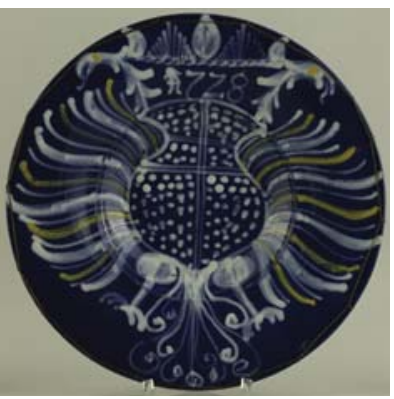

Dish, 1728. Inv. n. IMM 2931

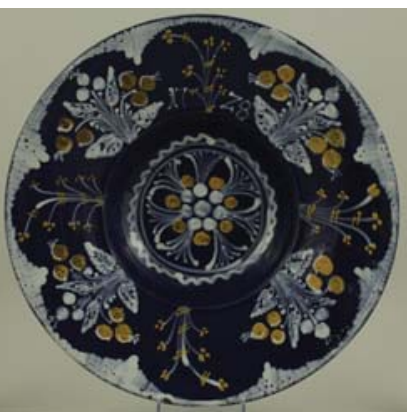

Dish, 1728. Inv. n. IMM 2910

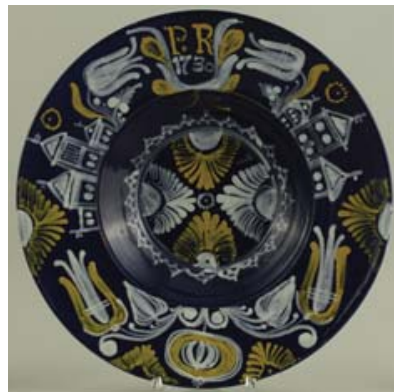

Dish, 1730. Inv. n. IMM 16154

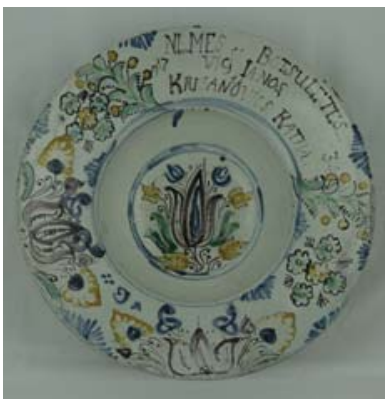

Dish, 1734. Inv. n. IMM 1954.340

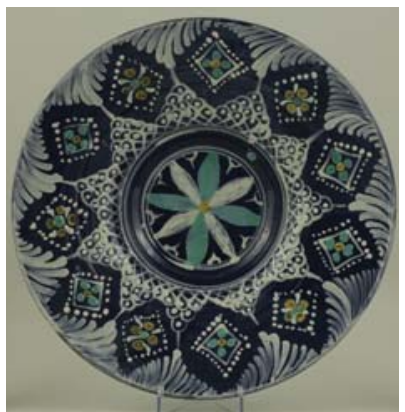

Dish, s.d. Inv. n. IMM 1959.966 
Plate 8

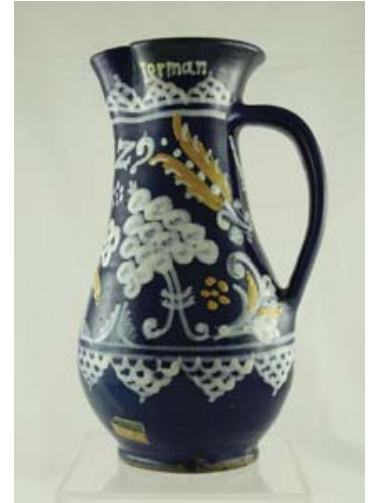

Jug, 1729. Inv. n. MNM 1954.393

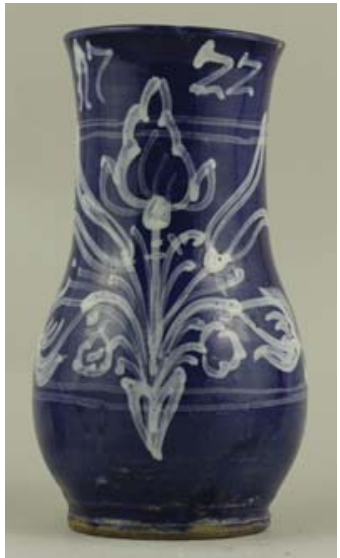

Pear-shaped jug, 1722. Inv. n. IMM 2941

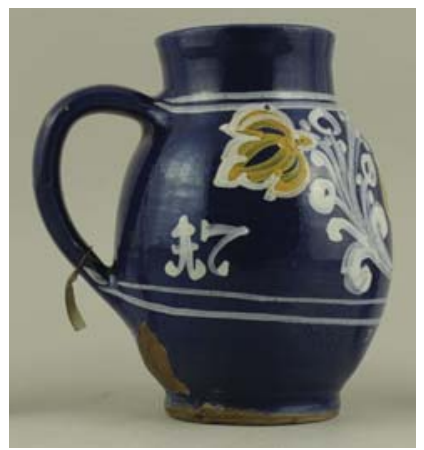

Jug, 1726. Inv. n. IMM 2900

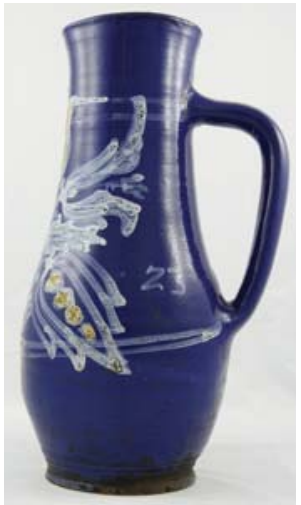

Pear-shaped jug, 1723. Inv. n. MNM 1961.46

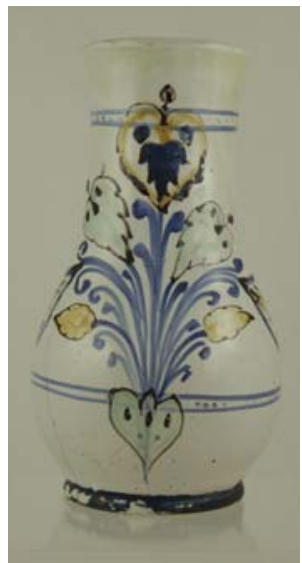

Pear-shaped jug, 1724. Inv. n. NM 51.31.500

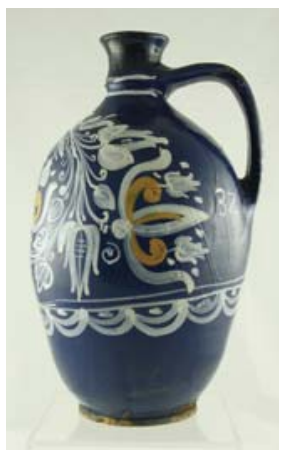

Jug. 1732. Inv. v. MNM 1594.394 


\section{Plate 9}

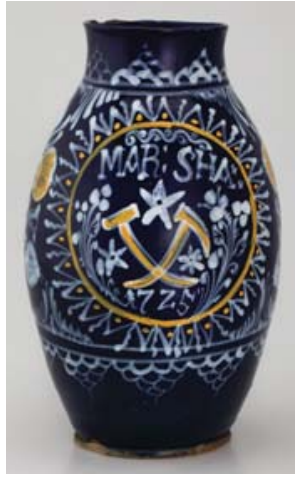

Jug with miners' symbols, 1725 . Inv. n. MNM 54.445

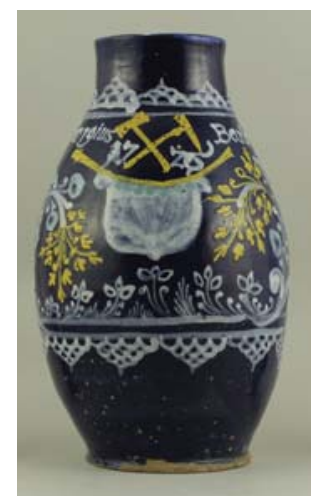

Jug with miners' symbols, 1726. Inv. n. IMM 2925

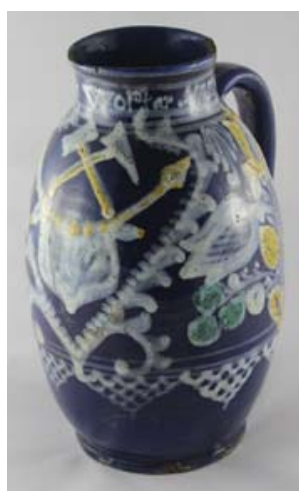

Jug with miners' symbols, 1735. Inv. n. GYBK 20682

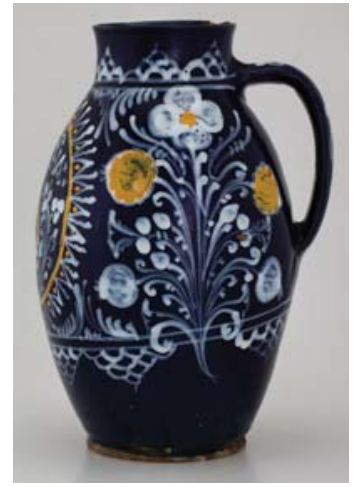

Jug with miners' symbols, 1725 . Inv. n. MBM 54.445

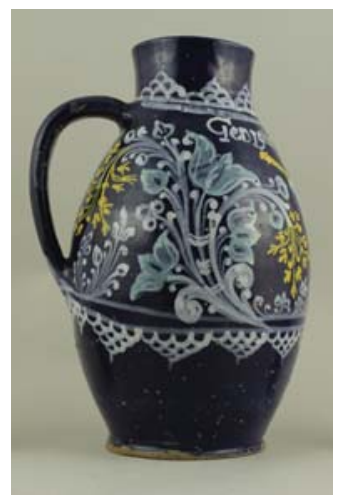

Jug with miners' symbols, 1726. Inv. n. IMM 2925

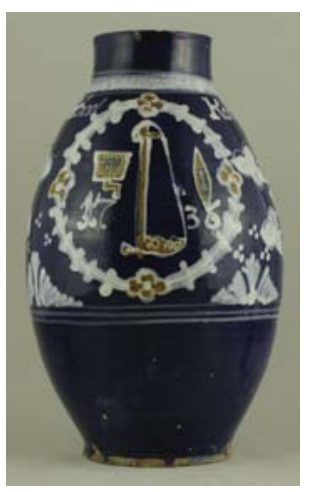

Jug with weavers' symbols, 1736. Inv. n. IMM 21800 


\section{Plate 10}

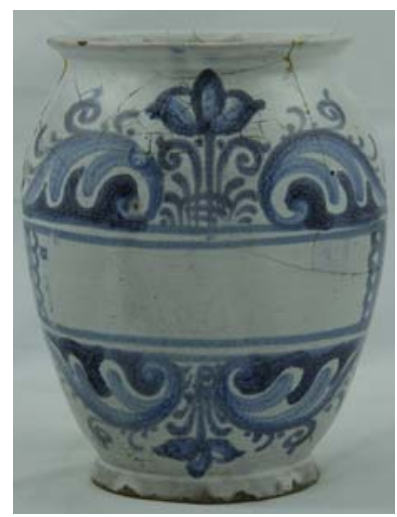

Albarello. Inv. n. MNM 1922.40

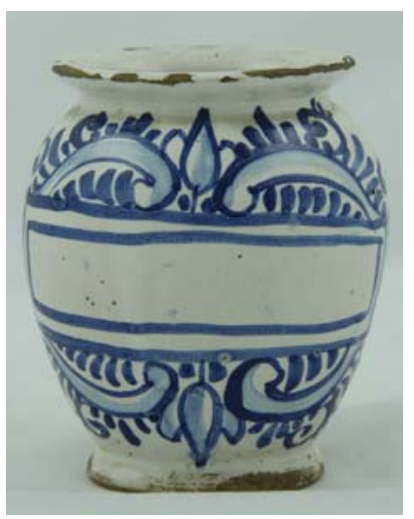

Albarello. Inv. n. MNM 1950.305

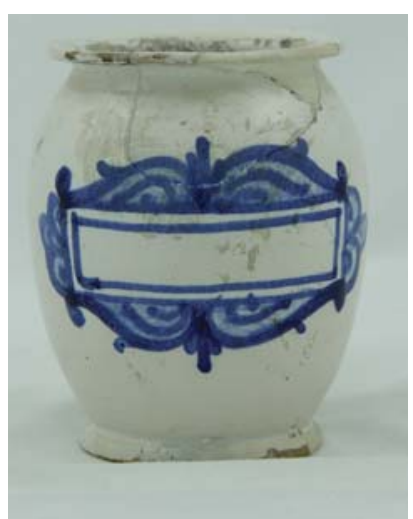

Albarello. Inv. n. MNM 1950.306

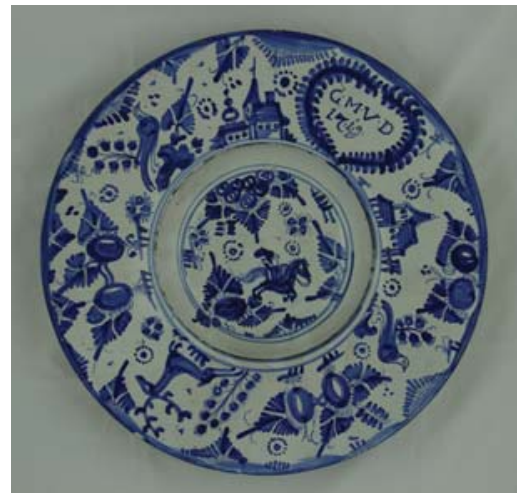

Dish, 1719. Inv. n. MNM 1954.334

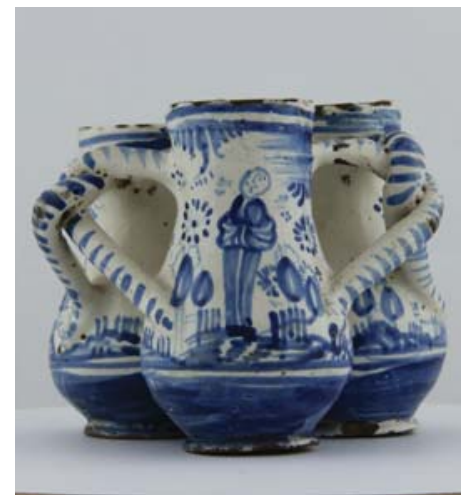

Triple jug. Inv. n. MNM 1978.108

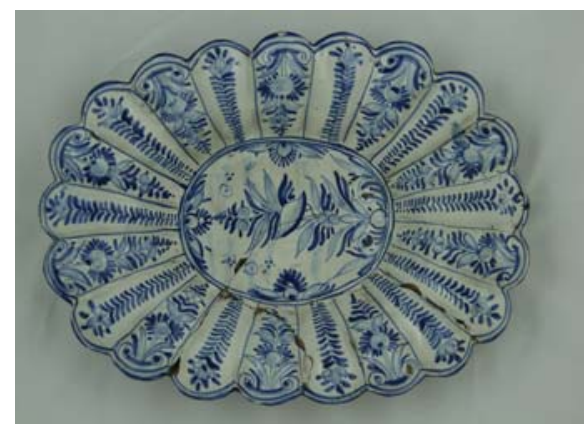

Fluted dish. Inv. n. MNM 1954.412 